\title{
NPK macronutrients and microRNA homeostasis
}

\author{
Franceli R. Kulcheski', Régis Côrrea², Igor A. Gomes², Júlio C. de Lima ${ }^{3}$ and \\ Rogerio Margis ${ }^{*}$.
}

' Departamento de Biofísica, Laboratório de Genomas e Populações de Plantas, Centro de Biotecnologia, Universidade Federal do Rio Grande do Sul, Porto Alegre, Brazil, ${ }^{2}$ Departamento de Genética, Universidade Federal do Rio de Janeiro, Rio de Janeiro, Brazil, ${ }^{3}$ Laboratório de Genética Molecular, Instituto de Ciências Biológicas, Universidade de Passo Fundo, Passo Fundo, Brazil

\section{OPEN ACCESS}

Edited by:

Andrzej Miroslaw Pacak, Adam Mickiewicz University, Poland

Reviewed by: Heiner Goldbach, University of Bonn, Germany

Fangsen $X u$, Huazhong Agricultural University,

China

*Correspondence: Rogerio Margis,

Departamento de Biofísica,

Laboratório de Genomas e Populações de Plantas, Centro de Biotecnologia, Universidade Federal do Rio Grande do Sul, Avenida Bento Gonçalves 9500, Setor IV, Prédio 43431, Sala 213,

Porto Alegre, RS, CEP, Brazil rogerio.margis@ufrgs.br

Specialty section: This article was submitted to Plant Nutrition,

a section of the journal Frontiers in Plant Science

Received: 10 March 2015 Accepted: 02 June 2015 Published: 16 June 2015

Citation:

Kulcheski FR, Côrrea R, Gomes IA, de Lima JC and Margis R (2015) NPK macronutrients and microRNA homeostasis.

Front. Plant Sci. 6:451. doi: 10.3389/fpls.2015.00451
Macronutrients are essential elements for plant growth and development. In natural, non-cultivated systems, the availability of macronutrients is not a limiting factor of growth, due to fast recycling mechanisms. However, their availability might be an issue in modern agricultural practices, since soil has been frequently over exploited. From a crop management perspective, the nitrogen $(N)$, phosphorus $(P)$, and potassium $(\mathrm{K})$ are three important limiting factors and therefore frequently added as fertilizers. NPK are among the nutrients that have been reported to alter post-embryonic root developmental processes and consequently, impairs crop yield. To cope with nutrients scarcity, plants have evolved several mechanisms involved in metabolic, physiological, and developmental adaptations. In this scenario, microRNAs (miRNAs) have emerged as additional key regulators of nutrients uptake and assimilation. Some studies have demonstrated the intrinsic relation between miRNAs and their targets, and how they can modulate plants to deal with the NPK availability. In this review, we focus on miRNAs and their regulation of targets involved in NPK metabolism. In general, NPK starvation is related with miRNAs that are involved in root-architectural changes and uptake activity modulation. We further show that several miRNAs were discovered to be involved in plant-microbe symbiosis during $\mathrm{N}$ and $\mathrm{P}$ uptake, and in this way we present a global view of some studies that were conducted in the last years. The integration of current knowledge about miRNA-NPK signaling may help future studies to focus in good candidates genes for the development of important tools for plant nutritional breeding.

Keywords: nitrogen, phosphorus, potassium, microRNAs, plant nutrition, plant-microbe symbiosis

\section{Introduction}

Nutrients in plants have important functions in osmotic regulation, cellular permeability, and may act as structural components and essential metabolites, being therefore critical for proper growth and development. Some of those nutrients, known as macronutrients, though, are required in relatively large amounts. Among these macronutrients, nitrogen $(\mathrm{N})$, phosphorus $(\mathrm{P})$, and potassium $(\mathrm{K})$ are three important limiting factors frequently added as fertilizers in modern agricultural schemes.

Plants have evolved several physiological and molecular adaptive responses to deal with the lack of nutrients. A better understanding about how those circuits are triggered, transduced and controlled may lead to the development of important tools for plant breeding and manipulation. 
Recent data have showed that classes of long and small noncoding RNAs (ncRNAs) play an important role during plant stress response (Kulcheski et al., 2011; Jeong and Green, 2013; Kumar, 2014), including in nutrient availability (Sunkar et al., 2012). The vast majority of those ncRNAs remain poorly understood, but others, like some microRNAs (miRNAs) have been extensively studied and characterized, especially as negative regulators of mRNA half-life and translation, consequently interfering with protein production.

Since miRNAs are involved in the regulation of virtually all cellular metabolic pathways, modulation of their biogenesis is of paramount importance for the maintenance of cellular homeostasis. Like mRNAs, miRNAs are mainly transcribed by RNA Polymerase II (Pol II) and are associated with factors involved in RNA splicing and processing, including addition of $5^{\prime} \mathrm{CAP}$ and $3^{\prime}$ polyadenylation (Xie et al., 2005; Bielewicz et al., 2013). Likewise, miRNA promoters have TATA box cis elements and are recognized by basic transcription initiation factors, such as transcription factor IIB (TFIIB), involved in the formation of Pol II pre-initiation complex (Megraw et al., 2006; Zhao et al., 2013). Therefore, miRNA biogenesis is temporally and spatially regulated during development, as well as in response to environmental factors. Due to their sessile nature, plants have efficiently integrated the miRNA response for the mitigation of several types of stresses.

Like other small ncRNAs, mature miRNAs are singlestranded molecules with 20-24 nucleotides (nt) in length. Those molecules, however, have a unique biogenesis mechanism. As the first step, miRNAs are produced from a particular type of stemloop precursor RNA, termed pri-miRNAs. The pri-miRNAs are generally transcribed by RNA Pol II and may contain several 100s of nucleotides (Rogers and Chen, 2013). In eukaryotes, a special class of RNase III enzyme called Dicer recognizes and degrades pri-miRNAs, generating a stem loop intermediate known as pre-miRNA. Pre-miRNAs are further processed into 20-24 nt duplex miRNAs. In plants, the two processing steps are mediated by a single enzyme, Dicer-like 1 (DCL1; Reinhart et al., 2002; Finnegan et al., 2003; Xie et al., 2004; Park et al., 2005). DCL1 dices stem-loop RNAs into 21 nt sequences, explaining the predominance of this small RNA size class in plants. Some precursors, however, can be degraded by other plant DCLs, generating miRNAs with different sizes (Margis et al., 2006; Rajagopalan et al., 2006; Vazquez et al., 2008; Ben Amor et al., 2009).

Dicer-like 1, however, depends on several other proteins to exert its activity, forming a complex frequently refereed as microprocessor. Proteins directly or indirectly associated with DCL1 includes the dsRNA binding proteins DRB1 (also known as HYL1) and Tough (TGH; Ren et al., 2012), the zinc finger protein Serrate (SE; Yang et al., 2006), the phosphatase C-terminal Domain Phosphatase-like 1 (CPL1; Manavella et al., 2012), the threonine binding protein Dawdle (DDL; Yu et al., 2008), the proline-rich protein Sickle (SIC; Zhan et al., 2012), the RNA binding protein Modifier of SNC1-2 (MOS2; Wu et al., 2013), proteins involved in RNA splicing, like Cap Binding protein 20 (CBP20), Cap Binding protein 80 (CBP80), and Stabilized 1 (STA1), and components of the transcriptional machinery, such as Negative on TATA 2b (NOT2b; Gregory et al., 2008; Kim et al., 2008; Laubinger et al., 2008). Each protein has a specific function in the processing complex, including recruitment of pri-miRNAs, assistance in dicing activity, post-translation modification of key components and binding and/or recruitment of RNA splicing and transcriptional factors, indicating that pri-miRNA transcription and processing might occur simultaneously.

Mature duplex miRNAs may also suffer edition before being incorporated into effector complexes known as RNA-Induced Silencing Complex (RISC). Modifications may include $3^{\prime}$ end methylation, base additions, or degradation (Yu et al., 2005; Ramachandran and Chen, 2008). Once in RISC, duplex miRNAs binds to effector proteins called Argonaute (AGO). One of the strands is removed and the other will guide the complex to target sequences. Depending on the base pairing between the two RNAs, AGO proteins may regulate target sequences by slicing or translation inhibition (Poulsen et al., 2013). Most of known miRNA targets are mRNAs, however, other ncRNAs (Fei et al., 2013) and transposons can also be regulated during reprogramming of germ lines (Creasey et al., 2014).

Several miRNA genes/families are conserved among plants. Those genes are usually highly regulated and target mRNAs coding for development-related transcriptional factors (Willmann and Poethig, 2007). For example, genes involved with vegetative phase transition and leaf polarity are directly or indirectly regulated by conserved miRNAs (Peragine et al., 2004; Nogueira et al., 2007). Accordingly, mutations in genes associated with miRNA biogenesis display strong developmental defects and in some cases are lethal (Jacobsen et al., 1999; Lu and Fedoroff, 2000; Morel et al., 2002). However, like any other gene, miRNA genes can be continuously gained and lost during evolutionary processes. Even in closely related plants, like the two model plants Arabidopsis thaliana and Arabidopsis lyrata, about $13 \%$ of miRNA genes are unique in each species (Fahlgren et al., 2010). Most of those young miRNAs are frequently associated with clade-specific processes, including several types of stresses (Willmann and Poethig, 2007). More specifically, miRNAs have already been associated in cold, drought, salt, oxidative, injury, and nutrient stresses, among others (Sunkar et al., 2012). In fact, $d r b 1$ and $c p b 80$ mutants from Arabidopsis are hypersensitive to the abscisic acid hormone (ABA), a key regulator of stress responses (Kim et al., 2008).

The regulation of gene expression, mediated by miRNAs in stress and development responses in plants, is enhanced by two mechanisms: amplification and migration. Depending on the size of the mature miRNA sequence, the number of binding sites to the target sequence and also the type of AGO associated, the miRNA-mediated regulation can trigger the recruitment of the amplification machinery containing the RNA-dependent RNA Polymerase 6 (RDR6; Fei et al., 2013). By creating novel dsRNAs from target-sequences, a plethora of small interfering RNAs (siRNAs) are produced by the action of DCL4 protein. Those siRNAs can also be incorporated in AGO-containing RISC complexes, creating a complex network of regulation (MacLean et al., 2010). Furthermore, both amplified siRNAs and 
miRNAs can move from cell-to-cell and eventually reach phloem cells, promoting a long-distance regulation (Sarkies and Miska, 2014).

These characteristics confer to miRNAs an efficient buffer capacity and, in concert with transcription factors, important hubs for both local and systemic gene regulation. In this review, we will focus on the role of miRNAs in response to the NPK macronutrient stresses, the three main growth-limiting elements that are widely used as fertilizers.

\section{Nitrogen and Plant miRNAs}

Nitrogen is an essential macronutrient required for plant growth and development. This element is required in large amounts in plant cells, not only as an important building block of amino acids, nucleic acids, and chlorophyll, but also due the pivotal regulator role in carbon and amino acid metabolism, as well as in protein synthesis (Frink et al., 1999; Cai et al., 2012). Plants absorb $\mathrm{N}$ from soil in the form of nitrate $\left(\mathrm{NO}_{3}{ }^{-}\right)$, ammonia/ammonium $\left(\mathrm{NH}_{3} / \mathrm{NH}_{4}{ }^{+}\right)$, or urea $\left[\mathrm{CO}\left(\mathrm{NH}_{2}\right)_{2}\right]$, and also as free amino acids or organic $\mathrm{N}$ through microbial symbiosis in legumes (Williams and Miller, 2001; Fischer et al., 2013). Since $\mathrm{N}$ is indispensable to plant growth, it is also associated with crop production improvement. In this way, millions of tons of nitrogenous fertilizers are added to the soil worldwide annually (Good et al., 2004). However this practice increases the costs of plant production and also contributes for a serious soil and water pollution due to an excess of $\mathrm{N}$ that remains in the environment (Good and Beatty, 2011; Fischer et al., 2013). Incomplete capture and poor conversion of $\mathrm{N}$ fertilizer also can causes global warming through emissions of nitrous oxide (Montzka et al., 2011). For this reason, one of the main goals of researches on plant nutrition is to improve the plant $\mathrm{N}$ uptake as well as its efficient use (Hirel et al., 2007).

The efficient use of $\mathrm{N}$ by plants includes its uptake, assimilation, translocation, and when the plant is aging, recycling, and remobilization (Masclaux-Daubresse et al., 2008; Chardon et al., 2010). Many efforts have been done to understand the molecular basis of plant responses to $\mathrm{N}$ and to identify $\mathrm{N}$ responsive genes. The complex and diverse physiological and biochemical changes involved in $\mathrm{N}$ metabolism suggest that a plethora of genes and metabolic pathways are necessary to allow plant adaptation according to the $\mathrm{N}$ presence or limitation. In this scenario, many studies comprising miRNAs responsive to $\mathrm{N}$ stimulus have been developed.

Several miRNAs have been characterized in association to $\mathrm{N}$ stresses (Pant et al., 2009; Liang et al., 2012) and are summarized in Table 1. Some of these miRNAs were observed to be upregulated or downregulated depending the specie, tissues, and experiment design. For example, reverse transcription quantitative real-time polymerase chain reaction (RT-qPCR) detected that some conserved miRNAs can be either repressed or induced in $\mathrm{N}$-limited seedlings of Arabidopsis (Pant et al., 2009). The rapessed (Brassica napus) phloem sap was investigated about the $\mathrm{N}$-responsive miRNAs, and in this species, it was observed that miR2111, miR169, and miR827like sequences were strongly dependent on the $\mathrm{N}$ status (Pant et al., 2009). Liang et al. (2012), through deep sequencing technology, observed that members from the same miRNA families displayed differential expression in response to $\mathrm{N}$ deficiency in Arabidopsis. One year later, Vidal et al. (2013) studying $\mathrm{N}$-responsive genes in Arabidopsis roots, discovered a new miRNA (miR5640) and its respective target (AtPPC3 protein) which seems to integrate the $\mathrm{N}$ and carbon metabolism. The AtPPC3 protein is one of the four phosphoenolpyruvate carboxylase isozymes and is involved in the carbon metabolism that catalyzes the $\beta$-carboxylation of phosphoenolpyruvate to yield oxaloacetate. In C3 plants and algae, AtPPCs are important for the production of carbon skeletons used for $\mathrm{N}$ assimilation. Despite, the missing information about AtPPC3 function in N metabolism, Vidal et al. (2013) observed that this protein was nitrate-induced, being a good candidate for further investigation.

In maize, Xu et al. (2011) studied a detailed response of miRNAs in shoots and roots under long-term and shortterm low $\mathrm{N}$ condition. The results were interesting, since they showed some miRNAs having different behavior across the different $\mathrm{N}$ starvation kinetic, like was the case of miR169 in roots. However, the other high conserved miRNA, miR172 presented the same profile in leaves in both experimental conditions. Investigating the molecular biology of miRNAs underlying $\mathrm{N}$ sensing/signaling in this same crop, Zhao et al. (2012) constructed four small RNA libraries from shoot and root under N-sufficiency and deficiency. The sequencing data analysis showed that in shoots and roots the expression of some conserved miRNAs was variable under $\mathrm{N}$ deficiency. Also, in this study, the authors showed that RT-qPCR and small RNA northern blot results are consistent with the results obtained by sequencing, which is not a rule, once in several cases, discrepancies are observed across those methodologies. Trevisan et al. (2012a,b) also observed the $\mathrm{N}$ effect on miR528ab, miR169ijk, miR166jkn, and miR408b transcripts accumulation. Since they employed the in situ hybridization methodology, the inspection of tissue localization of these miRNAs was possible. All miRNAs analyzed showed transcript accumulation in $\mathrm{N}$-supplied roots, while signals became weaker in $\mathrm{N}$-depleted roots. In $\mathrm{N}$-supplied roots, miR169ijk, and miR166jkn were present exclusively in the root vascular tissues, miR528ab in pericycle cells and miR408b in epidermis tissue. However miR169ijk was only found in nitrate-supplied root tips, while the others miRNA were detected also in N-deficient roots.

Rice is the other important crop which has being investigated about miRNAs expression under N stresses. Nischal et al. (2012) investigated microarray-based miRNA expression in $\mathrm{N}$-tolerant and $\mathrm{N}$-sensitive rice genotypes under low $\mathrm{N}$ condition. They detected the expression of some miRNAs and their respective targets. In both tissues analyzed, miRNAs were downregulated and their respective targets expressions were significantly higher in low $\mathrm{N}$-tolerant genotype than low $\mathrm{N}$-sensitive genotype. The majority of miRNAs targets identified were transcription factors and proteins associated with metabolic processes or 
TABLE 1 | N-responsive miRNAs with respective expression profiles according to different treatments, tissues, and species.

\begin{tabular}{|c|c|c|c|c|c|}
\hline Plant species & miRNAs & $\begin{array}{l}\text { Expression } \\
\text { profile }\end{array}$ & $\begin{array}{l}\text { Samples/ } \\
\text { tissue }\end{array}$ & $\mathbf{N}$ condition & Reference \\
\hline \multirow{5}{*}{$\begin{array}{l}\text { Arabidopsis } \\
\text { thaliana }\end{array}$} & miR156e, miR156g, miR157d & Upregulated & Seedlings & $\mathrm{N}$-deficient & Pant et al. (2009) \\
\hline & $\begin{array}{l}\text { miR169h, miR169i, miR169j, miR169k, miR169l, } \\
\text { miR169m, miR169n, miR398 }\end{array}$ & Downregulated & & & \\
\hline & miR160, miR780, miR826, miR842, miR846 & Upregulated & $\begin{array}{l}\text { Whole } \\
\text { seedlings }\end{array}$ & N-deficient & Liang et al. (2012) \\
\hline & $\begin{array}{l}\text { miR169, miR171, miR395, miR397, miR398, } \\
\text { miR399, miR408, miR827, miR857 }\end{array}$ & Downregulated & & & \\
\hline & $\operatorname{miR} 5640$ & Downregulated & Roots & $\begin{array}{l}1 \mathrm{~h} \text { after } \mathrm{N} \\
\text { addition }\end{array}$ & Vidal et al. (2013) \\
\hline \multirow[t]{2}{*}{ Brassica napus } & miR156, miR399 & Upregulated & Phloem sap & N-deficient & Pant et al. (2009) \\
\hline & miR159, miR169, miR2111 & Downregulated & & & \\
\hline \multirow[t]{2}{*}{ Glycine max } & $\begin{array}{l}\text { miR172l-3p, miR396bcdfg-5p, miR396bcg-3p, } \\
\text { miR398ab-3p, miR1511-3p, miR4413a-5p }\end{array}$ & Upregulated & Roots & $\begin{array}{l}\text { N-deficient } \\
\text { (short-term } \\
\text { treatment) }\end{array}$ & Wang et al. (2013)* \\
\hline & $\begin{array}{l}\text { miR156p-5p, miR171n-3p, miR171o-5p, } \\
\text { miR390ac-3p, miR482a-3p, miR4348-5p }\end{array}$ & Downregulated & & & \\
\hline \multirow[t]{2}{*}{ Oryza sativa } & $\begin{array}{l}\text { miR156, miR164, miR528, miR820, miR821, } \\
\text { miR1318 }\end{array}$ & Downregulated & Leaves & $\begin{array}{l}\mathrm{N} \text {-deficient } \\
\text { (low-N } \\
\text { tolerante/low-N } \\
\text { sensitive } \\
\text { genotype) }\end{array}$ & Nischal et al. (2012) \\
\hline & miR164, miR167, miR168, miR528 & Downregulated & Roots & & \\
\hline \multirow{2}{*}{$\begin{array}{l}\text { Phaseolus } \\
\text { vulgaris }\end{array}$} & miR167, miR169, miR319, miR399, miR408 & Downregulated & Leaves/roots & N-deficient & Valdés-López et al. (2010) \\
\hline & miR396 & Upregulated & Leaves & & \\
\hline \multirow{2}{*}{$\begin{array}{l}\text { Populus } \\
\text { tomentosa }\end{array}$} & miR393, miR395,miR396abe & Upregulated & Whole plantlets & N-deficient & Ren et al. (2015) \\
\hline & $\begin{array}{l}\text { miR159, miR160, miR162, miR166, miR167, } \\
\text { miR168, miR169, miR171, miR172, miR390, } \\
\text { miR396c, miR399, miR403, miR475, miR482, } \\
\text { miR1448, miR6427, miR6445, miR6462 }\end{array}$ & Downregulated & & & \\
\hline \multirow[t]{11}{*}{ Zea mays } & $\begin{array}{l}\text { miR167, miR169, miR395, miR399, miR408, } \\
\text { miR528 }\end{array}$ & Downregulated & Roots & $\begin{array}{l}\text { Long term } \\
\text { N-deficient }\end{array}$ & Xu et al. (2011) \\
\hline & miR164, miR172, miR827 & Upregulated & Leaves & & \\
\hline & $\begin{array}{l}\text { miR169, miR397, miR398, miR399, miR498, } \\
\text { miR528 }\end{array}$ & Downregulated & & & \\
\hline & $\begin{array}{l}\text { miR160, miR168, miR169, miR319, miR395, } \\
\text { miR399 }\end{array}$ & Upregulated & Roots & $\begin{array}{l}\text { Short-term } \\
\text { N-deficient }\end{array}$ & \\
\hline & $\operatorname{miR} 172$ & Upregulated & Leaves & & \\
\hline & miR397, miR398, miR827 & Downregulated & & & \\
\hline & miR162, miR167, miR394 & Upregulated & Shoots & $\mathrm{N}$-deficient & Zhao et al. (2012) \\
\hline & miR169, miR397, miR398, miR408, miR528s & Downregulated & & & \\
\hline & miR162, miR167s & Upregulated & Roots & & \\
\hline & $\begin{array}{l}\text { miR169, miR169cr, miR395abdefghijnp, miR397s, } \\
\text { miR408s, miR528s, miR395s, miR827 }\end{array}$ & Downregulated & & & \\
\hline & miR166jkn, miR169ijk, miR408b, miR528ab & Downregulated & Roots & $\mathrm{N}$-deficient & Trevisan et al. (2012a,b) \\
\hline
\end{tabular}

*These data are from RT-qPCR analysis, this paper also presents a huge set of miRNAs profile from deep sequencing analysis.

stress responses. In soybean, Wang et al. (2013) performed a massive sequencing of 16 different libraries. Using the sequencing data, they found that multiple members of the miR169 family were repressed in both roots and shoots of two soybean varieties under low $\mathrm{N}$ stress. Other conserved miRNA family, the miR156, also showed a variable response according the different experimental parameters. Aside from the sequencing data, the authors also performed RT-qPCR to predict some miRNAs expression (data showed in Table 1). Previous study exploring the miRNA expression in other legume, the blackbean (Phaseolus vulgaris), also detected the repression of some conserved in leaves and roots during $\mathrm{N}$ starvation; being the miR396 the unique conserved miRNA upregulated in leaves tissues (Valdés-López et al., 2010). 
Recently, the Chinese tree, Populus tomentosa, was investigated about its responsive miRNAs to $\mathrm{N}$ stress. In this study Ren et al. (2015) identified conserved and new miRNAs, and also employed RT-qPCR to determine the miRNAs dynamic and responses to low $\mathrm{N}$ stress at different time points. In general, they observed a variable behavior across the miRNAs families with a consistency among the members of each family. The family miR396 was the unique to present an inconsistency variation among their members, for example, miR396a, miR396b, and miR396e were upregulated in response to low $\mathrm{N}$ stress, but miR396c was downregulated.

Taking all these published work that were summarized above, as well as in Table $\mathbf{1}$, we can observe that in general the miRNAs tend to be downregulated during $\mathrm{N}$ deficiency. However, there are lots of variations according to different species, tissues, and experimental conditions that can affect a miRNA expression and results in an unstable behavior. Usually in these studies, the expression analyses are done in a high throughput way providing a huge amount of data. Global analyses are very helpful once they supply a plethora of possible miRNAs that are involved in particular process, facilitating the selection of potential candidates to be further explored. So, on the next sections we will discuss about some miRNAs, as also their respective targets, that have been deeply analyzed and experimentally confirmed to be involved in $\mathrm{N}$ response and symbiotic $\mathrm{N}$ fixation. The results of these studies are summarized in Figure 1.

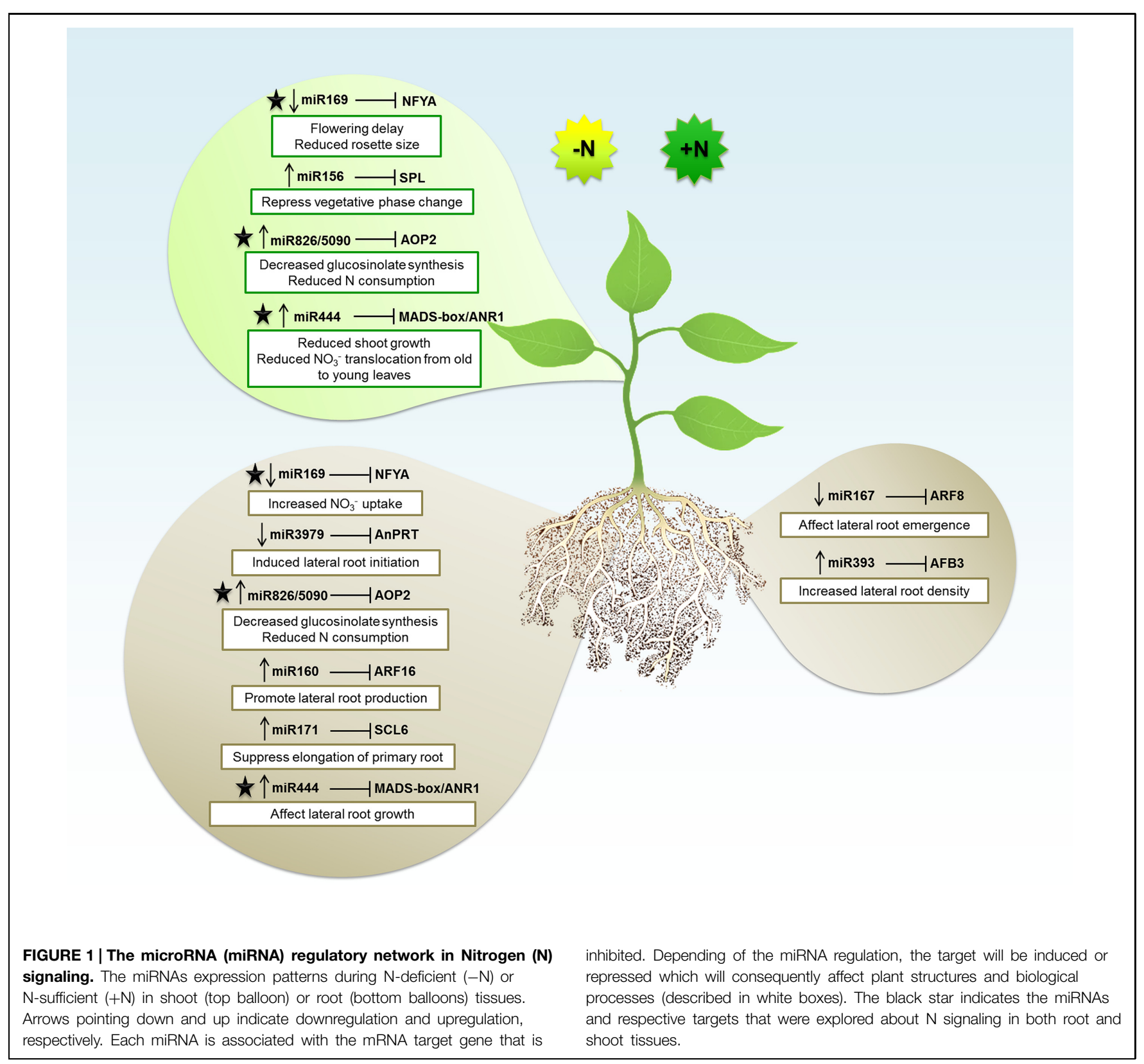




\section{The Nitrogen Responsive miRNAs and Their Targets \\ miR156 and Squamosa Promoter Binding Protein Like (SPL)}

The miR156 is one of the most conserved and ubiquitous miRNAs in plants and is conserved throughout the plant kingdom (Axtell and Bowman, 2008). In Arabidopsis, miR156 targets 11 out of the 17 members from the SPL gene family (Rhoades et al., 2002; Xing et al., 2010; Gou et al., 2011). The miR156 and its SPLs targets define an essential regulatory module that controls phase transitions, leaf trichome development, male fertility, embryonic patterning, and anthocyanin biosynthesis (Wang et al., 2009a, 2014b; Nodine and Bartel, 2010; Xing et al., 2010; Yu et al., 2010). SPL proteins play critical roles in maintaining normal growth throughout plant life cycle. These miRNAs are involved in phase change via their targets, members of the SPL transcription factors. The miR156a and miR156c levels have been shown to be repressed by a factor produced by leaf primordia, as defoliation generates high levels of miR156 (Yang et al., 2011). Recent work showed that the leaf-derived signal might be glucose or a glucose-derived metabolite, since glucose represses the expression of miR156 genes promoting vegetative phase change (Yang et al., 2013; Yu et al., 2013). These results suggest that products of photosynthesis can act as positive signals for the plant to proceed into the adult phase. Similarly, $\mathrm{N}$ limitation can induce the expression of miR156 in Arabidopsis seedlings (Pant et al., 2009; Liang et al., 2012; Fischer et al., 2013). Analysis of the transcriptome of N-limited plants shows that one of the miR156 targets, SPL3, is downregulated (Krapp et al., 2012), suggesting that a miR156/SPL3 module might act by repressing vegetative phase change under limiting $\mathrm{N}$ availability. Furthermore, miR156 acts as a negative regulator of miR172 by controlling miR172 expression via its targets SPL9 and SPL15 (Wu et al., 2009a). Consistently, N starvation represses miR172 in Arabidopsis leaves (Liang et al., 2012; Fischer et al., 2013). However, no changes in transcript levels of miR172 targets are induced by $\mathrm{N}$ starvation in Arabidopsis leaves (Krapp et al., 2012).

\section{miR160 and Auxin Response Factor 16 (ARF16)}

In a study performed with Arabidopsis, was demonstrated that the abundance of miR160 was strongly increased during $\mathrm{N}$-deficient compared with $\mathrm{N}$-sufficient conditions (Liang et al., 2012). In this study, the authors observed that the expression induction of miR160a was co-related with the downregulation of its ARFs targets under $\mathrm{N}$-deficient conditions. ARFs are DNA binding proteins that control auxin-regulated transcription and are only present in plants. They bind to auxin-responsive promoter elements, which are found in early auxin responsive genes. Some previous studies showed that miR160 regulates the number of lateral root by controlling ARF16, being this auxin responsive factor already characterized to control root cap formation (Wang et al., 2005). Investigating whether the accumulation of miR160 facilitates lateral root formation during $\mathrm{N}$-deficiency, Liang et al. (2012) produced transgenic plants overexpressing miR160a. As expected by the authors, the miR160 overexpressing mutants had higher number of lateral roots than control plants, once that $\mathrm{N}$-deficiency induces expression of miR160, which increases ARF16 degradation and consequently supports lateral root formation.

\section{miR167 and Auxin Response Factor 8 (ARF8)}

The complex process of adventitious rooting is controlled by several endogenous and environmental factors. Some years ago, Gutierrez et al. (2012) demonstrated that the auxin response factors ARF6 and ARF8, targets of the miR167, are involved in the induction of adventitious rooting. Once that is already known that $\mathrm{N}$ concentration can stimulate lateral root elongation (Zhang and Forde, 1998; Lopez-Bucio et al., 2003), Gifford et al. (2008) decided to investigate the role of miR167 and ARF8 in response to $\mathrm{N}$ stimulus in Arabidopsis. Analyzing how tissues respond separately and coordinate their responses to $\mathrm{N}$ signals, the authors looked for different gene expression in a range of cell types from inner to outer layers of root tissues. They found that ARF8 was highly expressed in the pericycle and the lateral root cap cells during $\mathrm{N}$ treatment, while its miRNA regulator was repressed. In wild type phenotypes, $\mathrm{N}$ causes an increase ratio of initiation versus emergence of lateral roots. According to Gifford et al. (2008), this is a strategy that plants employ to control root architecture under $\mathrm{N}$ variations. If the environment is rich in $\mathrm{N}$ signal, the lateral root formation is initiated; however, the stimulus for lateral root outgrowth only occurs under N-starvation. Additionally, these authors observed that transgenic Arabidopsis overexpressing miR167 and null mutants for arf8 exhibited a complete loss of $\mathrm{N}$ control over lateral root emergence. These finds showed that the cell-specific adjustment in ARF8 by miR167 transcripts can lead to the lateral root emergence regulation as a strategic response to $\mathrm{N}$ influx.

\section{miR169 and Nuclear Factor Y Subunit A (NFYA)}

In Arabidopsis, members from the transcription factors family NFYA also called heme-activated protein (HAP) or CCAATbox binding-factor $(\mathrm{CBF})$, were characterized to be regulated by miR169 (Jones-Rhoades and Bartel, 2004; Li et al., 2008). Plants NFYA have being associated with nodule differentiation and drought tolerance (Combier et al., 2006). During N starvation, was observed that three members of this family, NFYA3, NFYA5, and NFYA8, are strongly induced in shoots and roots, while their repressor miR169 is suppressed (Zhao et al., 2011). Nutrient deficiency, like $\mathrm{N}$, can trigger oxidative stresses signals and the NFYA5 was described to modulate downstream genes involved in oxidative stress responses, such as those encoding a subunit of the cytochrome b6-f complex, glutathione S-transferases (GST), peroxidases and an oxidoreductase family protein ( $\mathrm{Li}$ et al., 2008). In a previous study performed by Wenkel et al. (2006), the overexpression of NFYA (or HAP2) was associated with flowering delay due a reduction of the florigen Flowering locus $\mathrm{T}$ (FT) levels. Some years later, a study evaluating several miRNAs and their respective targets through mimicry assays, validated the miR169 and NFYA (HAP2), and also showed that the downregulation of miR169 caused reduced rosette size in Arabidopsis plants (Todesco et al., 2010). In the study performed by Zhao et al. (2011), they showed that miR169 was 
critical for the $\mathrm{N}$-starvation response in Arabidopsis. Analyzing transgenic Arabidopsis plants overexpressing miR169a, they showed a decrease in $\mathrm{N}$ accumulation. These plants showed higher sensitivity to $\mathrm{N}$ limitation comparing to the wild type, showing leaf yellowing, which can be related to the impaired capacity of $\mathrm{N}$-absorption since NFYA regulates the nitrate transporters NRT1 and NRT2 (Zhao et al., 2011). Interestingly, miR169 was also reported to be $\mathrm{N}$ responsive in maize and soybean (Xu et al., 2011; Liang et al., 2012; Trevisan et al., 2012b; Zhao et al., 2012; Wang et al., 2013; Zeng et al., 2014).

\section{miR171 and Scarecrow-Like 6 (SCL6)}

The SCL transcripts are already characterized to be targeted by miR171 (Wang et al., 2010). This miRNA was associated with primary root elongation decrease through cleavage of three SCL6 transcripts (Wang et al., 2010). Quantitative RT-PCR analyses demonstrated that the miR171c expression was threefold higher under $\mathrm{N}$-deficient than under $\mathrm{N}$-sufficient conditions. Consistently, the three miR171 targets were downregulated at the same conditions. These results point to a miR171 induction promoted by $\mathrm{N}$-starvation, which outcomes with a inhibitory effect over their targets (SCL6-II, SCL6-III, and SCL6-IV), and consequently repress the elongation of primary roots during this stress condition (Liang et al., 2012).

\section{miR393 and Auxin Signaling F-Box Protein 3 (AFB3)}

To investigate the small RNAs (sRNAs) role, Vidal et al. (2010) performed high throughput sequencing from Arabidopsis seedling submitted or not to $\mathrm{N}$ treatment. The authors observed that miR393 was induced by nitrate and also detected some target transcripts for this miRNA: a basic helix-loop-helix (bHLH) transcription factor and the auxin receptors TIR1, AFB1, AFB2, and AFB3. However, from all these miR393 known targets, only AFB3 was regulated by nitrate in roots under the experimental conditions. They showed that nitrate is able to transcriptionally induce expression of AFB3 in roots and that $\mathrm{N}$ metabolites produced after nitrate reduction and assimilation lead to a downregulation of AFB3 levels due to miR393 induction. This regulatory module, revealed an incoherent feed-forward mechanism that is induced by nitrate and repressed by $\mathrm{N}$ metabolites generated by nitrate reduction and assimilation. The observed regulation of AFB3 expression by nitrate and metabolites produced downstream of nitrate reduction might constitute a mechanism to rapidly and precisely adjust root growth depending on external and internal nitrate availability. As several miRNA targets encode transcription factors in plants, incoherent feed-forward loops are probably also a common feature of plant gene networks (Vidal et al., 2010). The rapid downregulation of AFB3 by miR393 provides a fine-tuned mechanism of the root system to dynamically respond to $\mathrm{N}$ in real time. In this same work, Vidal et al. (2010) investigated the miR393/ARF3 pathway analyzing the root architecture of ARF3 mutants and miR393 overexpressors, and they observed that these plants had primary and lateral roots growth unresponsive to $\mathrm{N}$ stimulus. With these findings, the authors conclude that miR393/ARF3 is the responsible mechanism to repress primary root elongation and induce lateral root emergence under the presence of $\mathrm{N}$. This interaction is an excellent example about how a small regulatory molecule integrates nitrate availability with auxin signaling.

\section{miR444 and MADS-Box Transcription Factor}

The monocot specific miR444 has been demonstrated to regulate four MIKC-type MADS-box transcriptional factor genes in rice (OsMADS23, OsMADS27a, OsMADS27b, and OsMADS57; Sunkar et al., 2005; Lu et al., 2008; Wu et al., 2009b; Li et al., 2010b; Yan et al., 2014). Phylogenetic analysis grouped the miR444 targets with Arabidopsis ANR1clade (Lee et al., 2003; Arora et al., 2007), which is a pivotal regulator in $\mathrm{NO}_{3}{ }^{-}$signaling pathway in lateral root growth (Zhang and Forde, 1998). Yan et al. (2014) showed that the miR444a regulates $\mathrm{NO}_{3}{ }^{-}$signaling in rice root growth and nitrate accumulation. Plants overexpressing this miRNA presented a decrease in the expression of the four MADSbox genes, and a reduced nitrate induced lateral root growth. These plants also showed altered primary and adventitious root architecture in response to different nitrate concentrations, indicating that miR444a participates in the $\mathrm{NO}_{3}{ }^{-}$signaling pathway through ANR1-homologous genes in rice. Additionally, overexpression of this miRNA caused a shoot decrease at the early seedling stage; as well as a higher $\mathrm{NO}_{3}{ }^{-}$level in rice shoots and roots under sufficient nitrate amount. An impaired N remobilization from old to young leaves was observed in these transgenic plants under $\mathrm{N}$-limiting conditions, suggesting that miR444a participates in nitrate translocation in shoots under $\mathrm{N}$-starvation conditions. So far, this work showed the crucial role of miR444 in $\mathrm{NO}_{3}{ }^{-}$signaling for root and shoots development and nitrate accumulation in rice.

\section{miR3979 and Anthranilate Phosphoribosyl-Transferase (AnPRT)}

The rice-specific miR3979 was reported to be preferentially expressed in roots tissues (Jeong et al., 2011; Jeong and Green, 2013). Once roots are responsible for $\mathrm{N}$ absorption, this miRNAs has being investigated about its regulation under $\mathrm{N}$ stress. Jeong et al. (2011) observed that miR3979 is downregulated on roots during $\mathrm{N}$ starvation. This miRNA was predicted to target a transcript encoding an AnPRT which is involved in tryptophan (Trp) biosynthesis. According to Zhao et al. (1998), Trp biosynthetic genes are generally induced by amino acid starvation as well as abiotic and biotic stresses. Besides to its role in protein biosynthesis, $\operatorname{Trp}$ is also involved on the production of secondary metabolites like the phytohormone auxin and the phytoalexin camalexin (Kutchan, 1995; Radwanski and Last, 1995; Jeong and Green, 2013). Once that auxin is involved in lateral root formation, the upregulation of Trp expression due the repression of miR3979 can be one of the regulatory mechanisms by which plants triggers lateral root initiation during N limitation.

\section{miR826/miR5090 and Alkenyl Hydroxalkyl Producing 2 (AOP2)}

Other miRNA characterized as $\mathrm{N}$-responsive is the miR826 which was described to be upregulated during $\mathrm{N}$ depletion 
(Liang et al., 2012). The miR826 targets the AOP2 gene, which encodes a 2-oxoglutarate-dependent dioxygenase, involved in glucosinolate biosynthesis. The data generated by high throughput sequencing showed an expressive induction of miR826 in roots and shoots by $\mathrm{N}$ starvation, associated with significant repression of its target, AOP2. Glucosinolates are a class of plant secondary metabolites rich in $\mathrm{N}$ and sulfur mainly found in Brassicaceae. For this reason, the suppression of AOP2 by miR826 could reduce the glucosinolates biosynthesis and consequently decrease the demand for $\mathrm{N}$. Two years later, He et al. (2014) detected a new miRNA, miR5090, from the complementary transcript of the miR826 gene. Similar to miR826, miR5090 is also induced by $\mathrm{N}$ deficiency, and both miRNAs target AOP2. To further prove the AOP2 is regulated by these miRNAs, an experiment overexpressing both miRNAs and the target were performed. The authors observed that AOP2 mRNA levels decreased considerably when coexpressed with both miRNAs compared to the control level. To confirm the cleavage site of AOP2, synonymous substitutions were introduced to generate miR826- and miR5090-resistant versions of AOP2. In this way, miR826 or miR5090 were coexpressed with the resistant version of AOP2, resulting in an unaffected AOP2 mRNA level. These data confirmed that AOP2 is the common target of miR826 and miR5090. In this same work, the authors also observed that AOP2 transcript level was negatively correlated with miR826 and miR5090 under $\mathrm{N}$ deficiency, corroborating with results observed by Liang et al. (2012). Besides of low AOP2 expression, the transgenic plants overexpressing miR826/5090 also accumulated fewer Met-derived glucosinolates, phenocopying the aop 2 mutants. Plants inhibit the expression of several glucosinolate synthesis genes as a mechanism to avoid the $\mathrm{N}$ consumption during N scarcity. So, in this work, He et al. (2014) showed that miRNA transgenic plants with less glucosinolate displayed enhanced tolerance to $\mathrm{N}$ starvation, including high biomass, more lateral roots, increased chlorophyll, and decreased anthocyanin. With this study was possible to figure out that the miR826/5090 - AOP2 regulatory system is involved in the plant adaptation to N-limited environment. Since AOP2 is a key enzyme in glucosinolate synthesis, its downregulation during $\mathrm{N}$ starvation decreases this pathway, allowing the use of $\mathrm{N}$ for other metabolites biosynthesis, like products necessary for plant growth and development during $\mathrm{N}$ limitation.

\section{miRNAs and Symbiotic N Fixation}

Plants have evolved several strategies to improve the nutrients uptake with the help of beneficial soil microorganisms, known as $\mathrm{N}$-fixing bacteria. They are the agents of the biological $\mathrm{N}$ fixation, which consists to reduce dinitrogen into $\mathrm{NH}_{4}{ }^{+}$ that is subsequently assimilated by the host plant. One of the best studied symbioses involves plant legumes and bacteria, collectively known as rhizobia. These partners cooperate in a $\mathrm{N}$-fixing symbiosis of major ecological importance that occurs on all continents and accounts for a fourth of the $\mathrm{N}$ fixed annually on earth (Masson-Boivin et al., 2009). In roots of host plants, the interaction starts with a chemical signaling between partners, which will be necessary to confirm host specificity. The symbiosis establishment involves several molecular signals, like plant flavonoid compounds (which will be recognized by compatible rhizobia species) and bacterial lipochitooligosaccharide which are known as Nod factors. An extensive review about legumes and rhizobium signal molecules involved in the interaction was published by Janczarek et al. (2015). The detection of Nod signals and the colonization of root hairs by rhizobia cells will trigger several root alteration with a consequent development of structures called infection threads. Concomitantly, several divisions occur in cortex and pericycle cells producing the nodule primordium. Infection threads transport rhizobia into the developing nodules, where they differentiate into bacteroides and fix N. Finally, symplastic and vascular connections are formed promoting transport of nutrients to and from the mature nodules (Murray, 2011; Turner et al., 2013). Aside from their roles in $\mathrm{N}$-sensing signaling, miRNAs are also being characterized in plant-microbe symbiosis. Extensive studies investigating miRNAs during symbiosis are being developed with the legumes Glycine max and Medicago truncatula.

One of the earliest studies involving miRNAs and $\mathrm{N}$ symbiotic fixation was performed by Subramanian et al. (2008). They investigated the potential miRNAs regulators of the earliest stages of nodule development under Bradyrhizobium japonicum inoculation. A kinetic evaluating three points after inoculation was carried out. The authors found some miRNAs, like miR168, and miR172 which were upregulated at the first hours and after decreased at a basal level. They found that miR159 and miR393 were continually induced, while miR160 and miR169 were downregulated during the response to rhizobia. Interestingly, two of those miRNAs, miR393, and miR160, were already identified in plant-pathogen interactions and seem to be involved in plant basal immunity promotion (Subramanian et al., 2008; Simon et al., 2009). In a related study, Wang et al. (2009b) investigating soybean nodules harvested 28 days post inoculation with B. japonicum detected four miRNA families (miR1507, miR1508, miR1509, and miR1510) in common to Subramanian et al. (2008) study. They also examined the expression of some miRNAs in nodule tissues. The miR172 and miR2107 were significantly upregulated in N-fixing nodules, while downregulation of miR396, miR1508, and miR1509 became evident in the nodules. Consistent with many previous studies, the majority of predicted targets detected by Wang et al. (2009b) are transcription factors, which are involved in hormone signaling and plant defense responses. Posterior studies have also corroborated the pioneer's works involving soybean nodulation. Barros-Carvalho et al. (2014) detected the presence of miRNAs miR1530, miR1520, and miR1522 in soybean root inoculated with $B$. japonicum. These miRNAs were, previously identified by Subramanian et al. (2008) and are involved in the early stages of nodulation. Other miRNA identified in this tissue was miR4393, early identified by Joshi et al. (2010). Interestingly, besides of some conserved miRNAs which are widely detected in plant genomes, the majority of miRNAs detected in these studies were Fabaceae specific miRNAs, like miR1507 to miR1510, or soybean species-specific as miR1520, miR1522, miR1530, 
miR2107, and miR4393. The G. max and M. truncatula were already characterized to have high proportion of species-specific miRNA genes (Cuperus et al., 2011). Lelandais-Briere et al. (2009) also detected $M$. truncatula specific miRNAs, like miR2586. In situ analysis demonstrated that this miRNA accumulated in the nodule meristem. This is very interesting, once speciesspecific miRNAs are developed later during plant evolution, these miRNAs could have evolved in the symbiotic interaction pathways.

Recent works are going deeper in understanding of how miRNAs can affect soybean nodulation. Turner et al. (2013) showed that ectopic expression of miR160 resulted in a decrease in nodulation. The authors overexpressed the miR160, which regulates the ARF10/16/17 (as discussed before), resulting in a silencing of a set of repressor auxin response factor transcription factors. These plants presented root hypersensitive to auxin and had significantly reduced nodule primordium formation. On the other hand, elevated expression of miR482, miR1512, and miR1515 caused increased nodulation in soybean (Li et al., 2010a). Opposite roles have been described for miR156 and miR172 in controlling the expression of both symbiotic and non-symbiotic hemoglobins to modulate the extent of nodulation in soybean, with enhanced levels of miR156 being consistent with reduced nodule numbers while miR172 acting as a positive regulator of nodule formation (Yan et al., 2013). One of the last discoveries involving the soybean miRNA172 and nodule regulation was done by Wang et al. (2014a) and proved that the miR172c modulates both rhizobium infection and nodule organogenesis. This miRNA was induced in soybean roots inoculated with either compatible B. japonicum or lipooligosaccharide Nod factor and was highly upregulated during nodule development. Reduced activity and overexpression of miR172c caused dramatic changes in nodule initiation and nodule number. In this way, miR172c regulates nodule formation by repressing its target gene, Nodule Number Control1, which encodes a protein that directly targets the promoter of the early nodulin gene, ENOD40. Interestingly, transcriptional levels of miR172c were regulated by both Nod Factor Receptor $1 \alpha / 5 \alpha$-mediated activation and by auto regulation of nodulation-mediated inhibition.

Medicago truncatula is a model organism broadly employed in genetic legume studies. Combier et al. (2006) explored this species to investigate the miR169 role during nodule development. As earlier demonstrated, miR169 targets the HAP2 transcription factor (Jones-Rhoades and Bartel, 2004), which was observed to be significantly induced in during symbiotic interactions (Combier et al., 2006). To prove the participation of miR169 and HAP2 during nodulation, these authors performed experiments involving miR169 overexpression and HAP2 silencing by RNAi. The miR169 overexpression caused a repression of HAP2 gene resulting in a deficient $\mathrm{N}$-fixation phenotype. The RNAi assay also showed a delay in nodule development being associated with a consequent inability of $\mathrm{N}_{2}$ fixation. Additionally, the HAP2 expression was restricted to the nodule meristematic zone, indicating that miR169 is controlling the spatial regulation of HAP2 during this stage in $\mathrm{N}$-fixing cell (Combier et al., 2006; Simon et al., 2009).
Other conserved miRNAs, like miR166 and miR396, have also being investigated in nodule development and symbiosis interactions in M. truncatula. The miR166 was observed to have a similar spatial expression of its target, a class III HD-ZIP transcription factor (Boualem et al., 2008). Overexpression of this miRNA leads to a reduction of HD-ZIP transcripts causing alterations in roots vascular bundle patterning and decreasing lateral root and nodule formation (Boualem et al., 2008; Simon et al., 2009). Similarly, miR396 was observed to be expressed in roots, with a differential pattern during lateral root and nodule formation (Bazin et al., 2013). It's known that this miRNA regulates a growth-regulating factor gene (GRF) and was proved to limit mycorrhizal colonization (Bazin et al., 2013). However, experiments overexpressing miR396 or inactivating it by mimicry didn't affect nodule density, morphology, or cellular organization after inoculation with the symbiotic bacteria Sinorhizobium meliloti. This scenario shows how important is to perform a deep investigation about a miRNA role, once is not possible to predict its function based only on a miRNA and its target expression. Although, both miRNA396 and GRF target are expressed in mature nodules, seems that they are not involved in the nodulation process.

A third species of legume was investigated about miRNAs and symbiotic $\mathrm{N}$ fixation is Lotus japonicus. De Luis et al. (2012) identified two miRNAs responsive to symbiotic infection and nodule function. The authors observed that the induction of a non-canonical miR171 isoform, which targets the key nodulation transcription factor Nodulation Signaling Pathway 2, correlates with bacterial infection in nodules. These finds were very interesting, since the conserved miR171 target a SCL gene family, showing the importance to explore the miRNA isoforms which can regulate alternative targets and provide different roles in plant biology. The second miRNA analyzed was the miR397, which is systemically induced in the presence of active $\mathrm{N}$-fixing nodules but not in non-infected or inactive nodule organs. This miRNA, which targets a member of the laccase copper protein family, is involved in $\mathrm{N}$ fixation-related copper homeostasis, being a link between two different nutrient metabolisms.

\section{Phosphorus and Plant miRNAs}

Phosphorus is an essential macronutrient required for plant growth, development, and propagation. The element corresponds to about $0.2 \%$ of plants dry weight and is a component of important macromolecules, being involved in the energetic metabolism and in transduction cell signaling pathways (Kuo and Chiou, 2011). The type of phosphate that can be directly assimilated by plants (orthophosphate or $\mathrm{Pi}$ ) is rather scarce in the soil due to its precipitation with cations and decomposition. These factors make $\mathrm{P}$ one of the less available macronutrients to plants. These, in turn, led to the development of several adaptations designed to surpass such deprivation (Raghothama, 1999).

The uptake and assimilation of $\mathrm{P}$ in plants is orchestrated by an intricate network of proteins and tissues. Two proteins are known to play key roles in the process: phosphate transporter 
1 (PHT1) and phosphate 1 (PHO1). PHT1 composes a family of transmembrane transport proteins expressed in roots and other plant tissues (Mudge et al., 2002). PHT1 proteins are able to use energy to cotransport $\mathrm{Pi}$ and $\mathrm{H}^{+}$and are therefore involved in Pi acquisition (Okumura et al., 1998). In Arabidopsis, there are at least nine genes (thirteen in Oryza sativa) encoding PHT1 (Okumura et al., 1998; Mudge et al., 2002) and Pi deprivation stimulates the expression of most of these genes, whose products are located in the plasma membrane of cortical and epidermal root cells, indicating their involvement in nutrient uptake (Karthikeyan et al., 2002). PHO1, on the other hand, is involved in the loading of acquired Pi into xylem, facilitating therefore the root-to-shoot transport of this macronutrient in plant (Poirier et al., 1991; Hamburger et al., 2002).

Upon Pi stress, plants trigger the expression of several homeostatic mechanisms called Pi Starvation Responses (PSR; Raghothama, 1999). It is believed that around 900-3000 genes are involved in these responses. Since, PHT1 and PHO1 proteins are central in the assimilation and allocation of $\mathrm{Pi}$ in plants, PSR try to maximize their expression through several direct or indirect pathways, including post-transcriptional regulation by miRNAs. The MYB transcription factors Phosphate Starvation Regulator 1 (PHR1) and Phosphate Starvation Regulator 1like (PHR1-LIKE1) have an important function in PSR by initiating a cascade regulation that ultimately leads to PHT1 and PHO1 over-accumulation. This function is mediated by directly or indirectly inducing their expression or by indirectly inhibiting their repressors. For example, PHR1 and PHR1LIKE1 induce the expression of Phosphate Transporter Traffic Facilitator 1 (PHF1), a protein that facilitates the transport of PHT1 to membranes, increasing therefore their availability for Pi assimilation (Gonzalez et al., 2005; Hsieh et al., 2009; Bayle et al., 2011). In phf1 Arabidopsis mutant plants, PHT1 is retained in the endoplasmic reticulum, being less available in membranes (Gonzalez et al., 2005; Bayle et al., 2011). Many genes associated to Pi starvation are also constitutively expressed in phf1 mutants, indicating the importance of PHF1 in the response regulation. At the same time, PHR1 and PHR1-LIKE1 may also trigger the expression of two miRNAs: miR399 and miR827.

The miRNAs miR399 and miR827 are important players in PSR since they repress genes involved in the repression of PHT1 and $\mathrm{PHO} 1$, contributing to their accumulation during stressed periods (Figure 2). The miRNA family miR399 $(\mathrm{a}-\mathrm{f})$ was the first one to be associated to Pi deficiency status. Members of the family are usually upregulated in response to the stress (Fujii et al., 2005) and when overexpressed by transgenes in Arabidopsis, the translocation of $\mathrm{Pi}$ from roots to shoots is enhanced and consequently the accumulation of $\mathrm{Pi}$ in shoots are from five to six times higher than in wild type plants (Chiou et al., 2006). In Solanum lycopersicum, in addition to the aforementioned effect, transgenic plants overexpressing miR399 also exhibit increased elimination of acid phosphatase and protons through roots, facilitating hydrolysis of organic phosphorus in the soil ( $\mathrm{Gu}$ et al., 2010). In spite of several genes been predicted as targets of miR399, only an ubiquitin binding enzyme E2 encoded by the PHO2 gene was validated as being regulated by it (Allen et al., 2005). This is primarily a gene expressed in the plant vascular system and downregulated in Pi deficient states. Multiple miR399 target sites were identified in the $5^{\prime}$-UTR region of $\mathrm{PHO} 2$ (Aung et al., 2006; Bari et al., 2006; Chiou et al., 2006). As an E2 ligase, $\mathrm{PHO} 2$ mediates the ubiquitination of the $\mathrm{Pi} / \mathrm{H}^{+}$transporters during normal $\mathrm{Pi}$ conditions, preventing their trafficking to membranes (Huang et al., 2013; Park et al., 2014). PHO2 also mediates a post-translational inhibition of PHO1 (Liu et al., 2012). Therefore, by repressing PHO2, miR399 contributes to the accumulation of both PHT1 and PHO1 during Pi starvation. Interestingly, miR399 species act as mobile signals, as their biogenesis take place at the shoots (Lin et al., 2008; Pant et al., 2008). Since, miR399* are also detected in roots, the miRNA is probably loaded as dsRNA into the phloem sap and systemically transported to roots. The identification of miR399 sequences in phloem sap of Pi-starved plants supports this model of action (Buhtz et al., 2008). On the other hand, miR399 family members can be regulated by the long non-coding gene Induced by Phosphate Starvation 1 (IPS1) in Arabidopsis. IPS1 has sequence complementary to miR399, but with unpaired nucleotides in the predicted cleavage site. It has been shown that IPS1 is not cleaved, but instead sequesters miR399 and block its action adding another level of regulation in PSR (Franco-Zorrilla et al., 2007).

Similar to miR399, miRNA, miR827 also repress a protein that is involved with PHT1 ubiquitination (Hsieh et al., 2009; Pant et al., 2009). Apart from being ubiquitinated during trafficking by PHO2, PHT1 may also suffer ubiquitination when already located in the plasma membrane by the Nitrogen Limitation Adaptation (NLA) protein, an E3 RING ubiquitin enzyme (Kant et al., 2011; Lin et al., 2013). NLA-mediated ubiquitination of PHT1 leads to endocytosis and degradation of the protein. Accordingly, a reduction of PHT1 endocytosis is observed in nla mutants (Lin et al., 2013). The post-transcriptional regulation of the NLA encoding gene by miR827, therefore, helps to stabilize PHT1 levels during stress conditions. Interestingly, $O$. sativa miR827 apparently also coordinate Pi stress responses, but by an independent pathway, since NLA homologues are not targeted by the miRNA in the plant (Lin et al., 2010; Wang et al., 2012).

Apart from miR399 and miR827, several other miRNA families have been associated to Pi responses (Table 2). Some of them are young clade-specific miRNAs, acting on specific molecular adaptations in response to $\mathrm{Pi}$ issues, while others are highly conserved (Hsieh et al., 2009; Pant et al., 2009; Gu et al., 2010; Lin et al., 2010; Lundmark et al., 2010; Matts et al., 2010; Valdés-López et al., 2010; Zeng et al., 2010; Kuo and Chiou, 2011). In a particular species, some miRNA families are up or downregulated in one or more tissues. There are still some families which are exclusively expressed in one plant tissue. This spatial limited activation of miRNAs is related to particular ways in which these areas organize their responses to $\mathrm{P}$ deficiency. In Lupinus albus, 35 miRNAs families were identified as differentially expressed; roots, stems, and leaves had, respectively, 24,15 , and 22 miRNAs families up or downregulated, demonstrating the possible overlapping nature of the response (Zhu et al., 2010). However, most of the conserved miRNAs misregulated under PSR are also responsive to other types of stresses, including nutrient deprivation. Their functions 


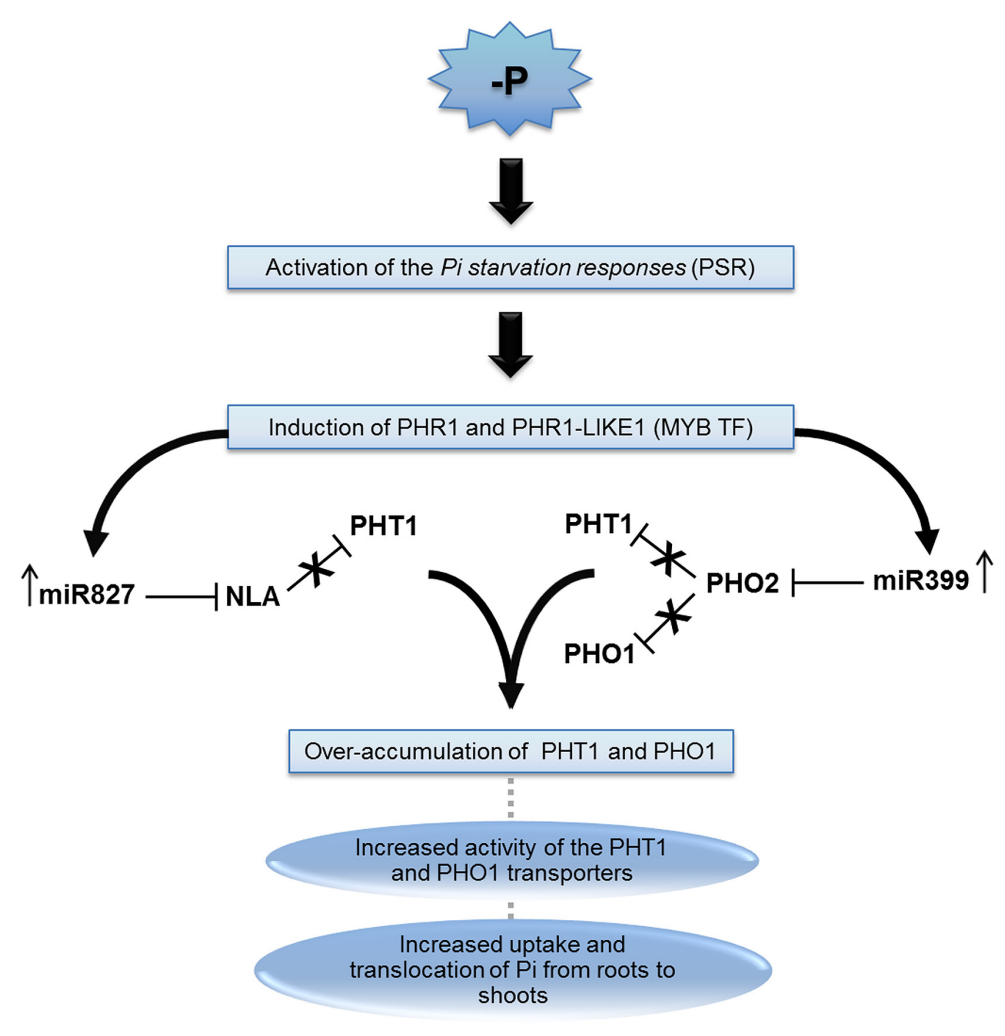

FIGURE 2|The miRNA399 and 827 pathway involved in plant P-deficiency. $\mathrm{Pi}$ starvation triggers the homeostatic mechanism known as "Pi starvation responses" (PSR), which leads to induction of MYB transcription factors (MYB-TF) called Phosphate Starvation Regulator 1 (PHR1) and PHR1-like proteins. The increased levels of these proteins are related with an upregulation of miR399 and miR827. These
miRNAs repress phosphate 2 (PHO2) and Nitrogen Limitation Adaptation (NLA), respectively. Both proteins are involved in the repression of phosphate transporter 1 (PHT1), and $\mathrm{PHO} 2$ also repress PHO1. Repression of NLA and PHO2 leads to PHT1 and PHO1 accumulation and consequently increase the $\mathrm{Pi}$ uptake as well as the accumulation of $\mathrm{Pi}$ in shoots. are therefore probably associated to general responses triggered in different types of stress conditions.

\section{miRNA, Phosphorus, and Mycorrhiza Symbiosis}

One of the most widespread adaptations to $\mathrm{P}$ deficiency is the interaction with arbuscular mycorrhizal fungi. In this interaction, fungi promote a more efficient uptake of water and nutrients $(\mathrm{P}$ among them) by roots and simultaneously receive carbohydrates required for their metabolism (Delaux et al., 2013).

microRNAs are one of the mechanisms used by plants in the regulation of this symbiosis. In the model species $M$. truncatula, several miRNAs have already been predicted as participants in this physiological response (Devers et al., 2011). The miR171h operates in the spatial regulation of fungi root colonization by targeting the gene encoding Nodulation Signaling Pathway 2 (NSP2), required for the production of stimulatory plant hormones (Lauressergues et al., 2012). The miR396, which exerts control over several transcription factors related to root development, undertakes a repressive action in mycorrhizal colonization in this species. Mutants overexpressing this miRNA were less colonized than control plants, while those that inactivated the same miRNA were significantly more colonized by AM fungi (Bazin et al., 2013). In M. truncatula and Nicotiana tabacum miR399 was also overaccumulated in mycorrhizal tissues in comparison to non-mycorrhizal ones indicating a possible role in this interaction (Branscheid et al., 2010). The miR5229, whose expression is detected only in mycorrhizal cells, has a Heme peroxidase as a potential target (Devers et al., 2011). The miR169, which targets the TF MtHAP2-1, a member of the CCAAT-binding family, was reported to be expressed in mycorrhizal roots (Combier et al., 2006). Additionally, miR160c was demonstrated to be another miRNA induced in mycorrhizal tissues, while miR5204, was detected to localize among the arbuscules as well as to be phosphate responsive (Devers et al., 2011).

\section{Potassium and Plant miRNAs}

Potassium $\left(\mathrm{K}^{+}\right)$is an essential plant macronutrient involved in several signaling pathways. It is important for the metabolic adjustment during plant development and reproduction, yield and responses to salinity, drought, cold, high light, and hormones (Bose et al., 2014a,b,c; Demidchik et al., 2014; Straltsova et al., 2014; Zorb et al., 2014; Daras et al., 2015; Zhang et al., 2015). 
TABLE 2 | P-responsive miRNAs with respective expression profiles in different tissues and species during P-starvation.

\begin{tabular}{|c|c|c|c|c|}
\hline Plant species & miRNAs & $\begin{array}{l}\text { Expression } \\
\text { profile }\end{array}$ & Tissue & Reference \\
\hline \multirow[t]{5}{*}{$\begin{array}{l}\text { Arabidopsis } \\
\text { thaliana }\end{array}$} & $\begin{array}{l}\text { miR156, miR399, miR778, miR827, miR2111-5p, } \\
\text { miR2111-3p }\end{array}$ & Upregulated & Root & $\begin{array}{l}\text { Hsieh et al. (2009), Pant et al. (2009), } \\
\text { Lundmark et al. (2010) }\end{array}$ \\
\hline & $\begin{array}{l}\text { miR163, miR399, miR778, miR827, miR828, } \\
\text { miR2111-5p, miR2111-3p }\end{array}$ & Upregulated & Stem & \\
\hline & miR169, miR395, miR398, miR402 & Downregulated & Root, stem & \\
\hline & $\begin{array}{l}\text { miR399, miR447, miR778, miR827, miR2111-5p, } \\
\text { miR2111-3p }\end{array}$ & Upregulated & Seedling & \\
\hline & miR169, miR398 & Downregulated & & \\
\hline \multirow[t]{2}{*}{ Glycine max } & miR159 & Upregulated & Root & Zeng et al. (2010) \\
\hline & miR166, miR319, miR398 & Downregulated & & \\
\hline \multirow[t]{6}{*}{ Lupinus albus } & $\begin{array}{l}\text { miR156, miR159, miR160, miR164, miR166, } \\
\text { miR167, miR168, miR319, miR396, miR437, } \\
\text { miR809, miR830, miR845, miR857, miR895, } \\
\text { miR896, miR1222 }\end{array}$ & Upregulated & Root & Zhu et al. (2010) \\
\hline & $\begin{array}{l}\text { miR168, miR171, miR395, miR399, miR447, } \\
\text { miR477, miR818, miR863, miR866, miR903 }\end{array}$ & Downregulated & & \\
\hline & $\begin{array}{l}\text { miR171, miR395, miR447, miR472, miR818, } \\
\text { miR854, miR866, miR903, miR904 }\end{array}$ & Upregulated & Stem & \\
\hline & $\begin{array}{l}\text { miR159, miR164, miR166, miR319, miR857, } \\
\text { miR895 }\end{array}$ & Downregulated & & \\
\hline & $\begin{array}{l}\text { miR168, miR171, miR395, miR399, miR447, } \\
\text { miR477, miR818, miR863, miR866, miR903 }\end{array}$ & Upregulated & Leaf & \\
\hline & $\begin{array}{l}\text { miR156, miR159, miR160,miR164, miR166, } \\
\text { miR167, miR396, miR397, miR530, miR830, } \\
\text { miR857, miR896 }\end{array}$ & Downregulated & & \\
\hline \multirow[t]{2}{*}{$\begin{array}{l}\text { Medicago } \\
\text { trunculata }\end{array}$} & $\begin{array}{l}\text { miR5229a,b, miR5206, miR160f, miR5205, } \\
\text { miR169d,l, miR169d,e.2,l,m, miR160c, miR171h, } \\
\text { miR167, miR5244, miR5232, miR5281b-f, } \\
\text { miR5250, miR2086, miR166b.2,c.2,f-2, miR396b, } \\
\text { miR5213, miR162 }\end{array}$ & Upregulated & (AM related) & Devers et al. (2011) \\
\hline & miR4414a, miR5285a-c & Downregulated & & \\
\hline Orysa sativa & miR399, miR827 & Upregulated & Root, stem & Zhou et al. (2008), Lin et al. (2010) \\
\hline Panicum virgatum & miR399 & Upregulated & Seedling & Matts et al. (2010) \\
\hline \multirow[t]{3}{*}{ Phaseolus vulgaris } & miR399 & Upregulated & Root, leaf & Valdés-López et al. (2010) \\
\hline & $\operatorname{miR} 157$ & Upregulated & Nodules & \\
\hline & miR397, miR398 & Downregulated & Leaf & \\
\hline \multirow{4}{*}{$\begin{array}{l}\text { Solanum } \\
\text { lycopersicum }\end{array}$} & miR319, miR394, miR399 & Upregulated & Root & Chiou et al. (2006), Gu et al. (2010) \\
\hline & miR399 & Upregulated & Stem, leaf & \\
\hline & miR158, miR862 & Downregulated & Root & Gu et al. (2010) \\
\hline & $\begin{array}{l}\text { miR158, miR169g, miR172, miR172b, miR319, } \\
\text { miR398, miR771, miR775, miR837 }\end{array}$ & Downregulated & Leaf & \\
\hline
\end{tabular}

Each plant species has its physiological mechanism to the uptake of $\mathrm{K}^{+}$. The efficiency of the uptake and physiological role of $\mathrm{K}^{+}$ has to be considered when improving crop yield, plant tolerance to biotic and abiotic stresses (Zorb et al., 2014). A diverse set of genes coding for $\mathrm{K}^{+}$channels and ion transporters has been functionally characterized to unravel the molecular physiology of $\mathrm{K}^{+}$in plants (Schroeder et al., 1994; Chen et al., 2008; Adams and Shin, 2014; Cherel et al., 2014). Genes related to the homeostasis of potassium in plants belong to classes of AKT1 and KT/KUP/HAK types, which code for ion channels and ion transporters, respectively (Adams and Shin, 2014). In cell membranes, $\mathrm{K}^{+}$channels have different physiological roles depending on where they are functional. If expressed in guard cells, they function in the net influx of $\mathrm{K}^{+}$and, if expressed in root cells, they function in the low and high affinity uptake of $\mathrm{K}^{+}$ (Schachtman, 2000). This differential expression reflects a crucial role of $\mathrm{K}^{+}$channels in the uptake and water balance, osmotic potential and, in transpiration mechanisms. Also, transport proteins underlie long distance - from root xylem to the shoots and intracellular movement of $\mathrm{K}^{+}$(Adams and Shin, 2014). Under low amounts readily available in the soil, plants have to trigger a bunch of complex molecular mechanisms to fine tune the absorption, transport, and efficient use of $\mathrm{K}^{+}$(Cherel et al., 2014). 
In plants, miRNAs are also known to be involved a wide range of fine-tuned controls during development and in response to a variety of stresses (de Lima et al., 2012). In humans, a few reports reveal the regulatory role of miRNAs and potassium channel genes in the physiology of heart and lung (Li et al., 2013, 2014; Tatro et al., 2013). However, it is far from clear how miRNAs are directly affected by the uptake and physiology of potassium in plants. So far, the unique miRNA investigated with respect to $\mathrm{K}^{+}$signaling was the monocots specific miR444a. In the work performed by Yan et al. (2014) miR444 was deeply evaluated about its involvement in $\mathrm{N}$ and $\mathrm{Pi}$ accumulation. However, the authors also explored the expression profile of this miRNA and its respective targets (MADS-23, MADS-27a, MADS-27b, and MADS-57) during $\mathrm{K}^{+}$deprivation in rice roots. This condition caused a slightly decrease of miR444a levels. MADS-23 target was strongly induced compared to the control situation (Figure 3). MADS-box genes encode a family of transcription factors and are associated with several developmental regulatory pathways, from root to flower and fruit development (Becker and Theißen, 2003). Other possible candidate to be investigated is the plant conserved miRNA miR167 which putatively targets ion transporters and genes coding for ion channel proteins (Griffiths-Jones et al.,
2006; Zhang et al., 2013). In induced leaf senescence of rice plants, miR167a-3p putatively targets intracellular trafficking and vesicular transport genes (Xu et al., 2014). Another interesting hypothesis emerges with the competition of $\mathrm{NH}_{4}^{+}$and $\mathrm{K}^{+}$ for protein transporters in barley and Arabidopsis (ten Hoopen et al., 2010) and the possibility of miRNA regulation. The presence of $\mathrm{NH}_{4}^{+}$in potassium containing medium favors nitrogen uptake by HAK5 protein, which is suggested to be a high affinity $\mathrm{K}^{+}$transporter (ten Hoopen et al., 2010). Under this nutrition circumstance, the protein AKT1 turns to be the main $\mathrm{K}^{+}$uptake protein even in low $\mathrm{K}^{+}$concentrations. Additionally, in silico tools can point to some $\mathrm{K}^{+}$transporters proteins, like $\mathrm{AKT}, \mathrm{HAK}$, and $\mathrm{HKT}$, as potential target sites for miRNAs in monocots and dicots species. Based on these findings, a dual ion uptake and a possible miRNA basedregulation point to a fine tuned physiological role of ion transport in plants (Figure 3, right). Undoubtedly, miRNAs have important physiological roles in plants under abiotic conditions and nutrient availability in soils. However, the targeting of potassium transporter genes by miRNAs remains to be validated and the dual ion uptake mediated by miRNAs remains to be investigated in detail.

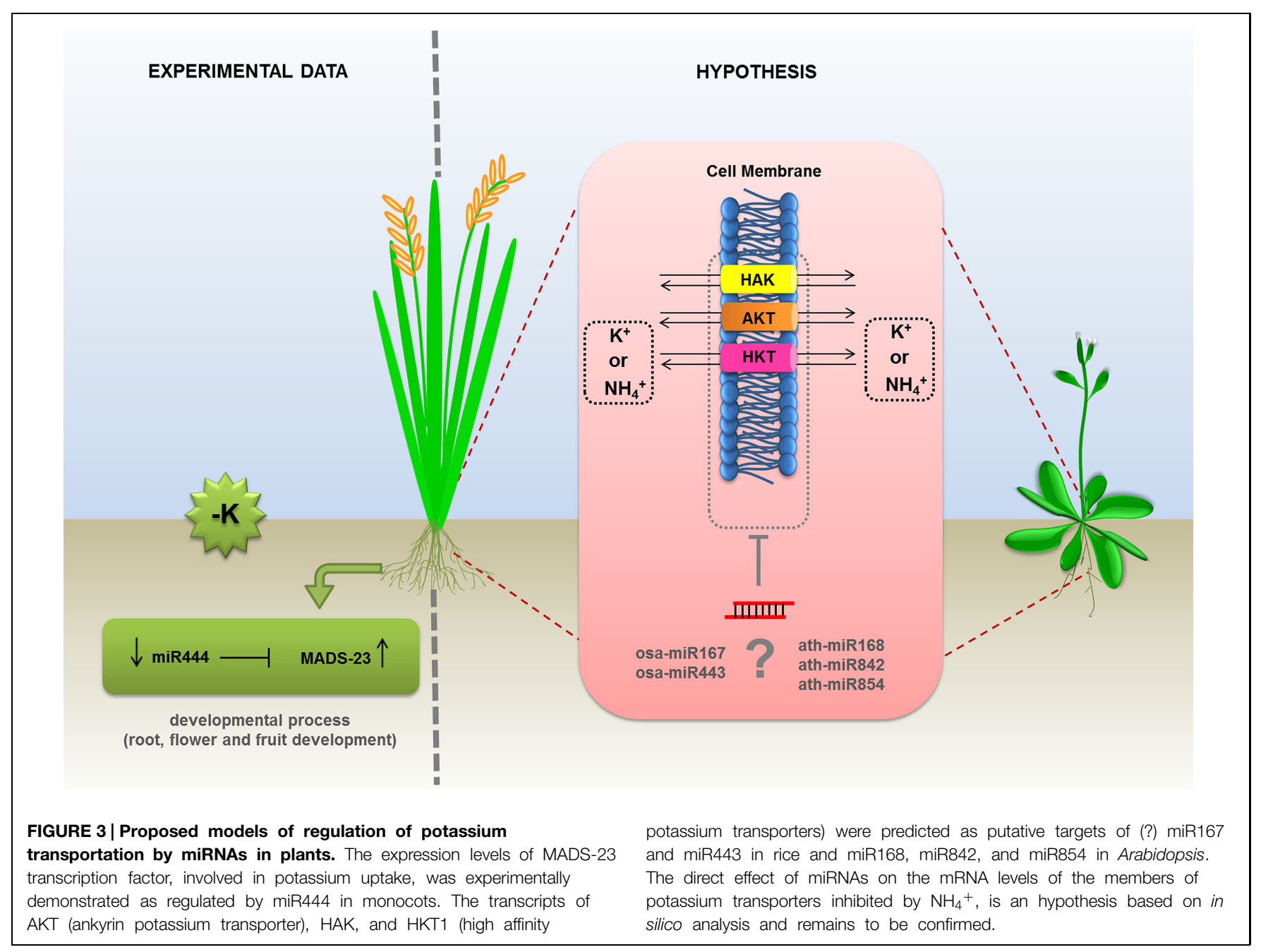


A range of previous works discussed the counteraction between miRNAs and putative ion transporters and genes coding for proteins that are potentially potassium dependent, as well as other proteins and miRNAs that have a convincing role in plant nutrition (Pant et al., 2009; Buhtz et al., 2010; Kehr, 2013). Additionally, targeted genes are evaluated based on miRNA ability to chop mRNAs. Although it has been proposed that translation inhibition is not a major miRNA regulatory mechanism in plants, the analysis of protein levels could confirm those ion transporters and other miRNA targets that were based on bioinformatics approaches (Chen, 2004; Voinnet, 2009).

Differential regulation and functions of $\mathrm{K}^{+}$responsive genes are widely cited in the literature (Cherel et al., 2014). High throughput analyses expand the view that ion transporters and protein channels are putatively regulated by a series of miRNAs. Although it still has to be extensively and experimentally confirmed, it is suggested that miRNAs play a pivotal role in the regulation of genes coding for proteins that sense, uptake and transport $\mathrm{K}^{+}$in plants.

\section{Concluding Remarks and Future Perspectives}

It has been very well documented that environmental changes can affect miRNA levels in plants. In this context, it would be expected that nutrient availability should also affect miRNA levels and homeostasis. In this review, we described a series of studies demonstrating how the macronutrients $\mathrm{N}, \mathrm{P}$, and $\mathrm{K}$ can affect miRNAs levels, triggering their increase or decrease, with an associated effect on the expression of different target genes. Both, excess or low level of nutrients can be sensed by plants as and abiotic stress. This will trigger a series of common mechanisms or specific strategies to face an emerging stress situation. Since the role of a miRNA is directly associated with its target function, we could observe that the majority of miRNAs involved in NPK deprivation are associated with mechanisms involved in the adaption to stress conditions. Actually, it was difficult to clarify about how the miRNAs are involved in $\mathrm{K}^{+}$metabolism, once the literature is still scarce to help to understand the molecular basis of $\mathrm{miRNA} / \mathrm{K}^{+}$interaction in plants. However, based on the hypothesis that miR444 is involved in the $\mathrm{K}^{+}$signaling, we can suppose that a control of root development can also be involved in $\mathrm{K}^{+}$metabolism. For $\mathrm{N}$ and $\mathrm{P}$ pathways in plants, the miRNAs roles have been extensively explored, and several routes were already very well characterized. In general, $\mathrm{N}$ and $\mathrm{P}$ starvation, affect miRNAs that will regulate genes involved in the

\section{References}

Adams, E., and Shin, R. (2014). Transport, signaling, and homeostasis of potassium and sodium in plants. J. Integr. Plant Biol. 56, 231-249. doi: 10.1111/jipb.12159

Allen, E., Xie, Z., Gustafson, A. M., and Carrington, J. C. (2005). microRNAdirected phasing during trans-acting siRNA biogenesis in plants. Cell 121, 207-221. doi: 10.1016/j.cell.2005.04.004

Arora, R., Agarwal, P., Ray, S., Singh, A. K., Singh, V. P., Tyagi, A. K., et al. (2007). MADS-box gene family in rice: genome-wide identification, organization uptake or reallocation of these nutrients. At the morphological and physiological level, miRNAs were proved to affect root architecture (suppressing primary root elongation, increasing lateral root), controlling $\mathrm{NO}_{3}{ }^{-}$or Pi transporters, controlling shoot growth, affecting vegetative phase transition, and managing these nutrients leakage (Figures 1 and 2). Since some miRNAs are critical in NPK metabolism control and are related to plant adaption during these nutrients stresses, we must consider their potential use in plant genetic breeding.

So far, we looked for miRNAs that were commonly involved in the three nutrients routes, but no report was detailing a route involving a miRNA regulation for NPK. A recent work analyzed the miR444 expression during $\mathrm{N}, \mathrm{P}$, or $\mathrm{K}$ depletion (Yan et al., 2014). Changes in this miRNA was observed for all three nutrients treatment, however, the mechanism behind this behavior were just explored for $\mathrm{N}$ metabolism. In this way, we observed that there is a vast unexplored field which can address the regulation of miRNAs when plants are exposed to more than one nutrient stress. Another important consideration about miRNA and NPK signaling is that analyzing the works which describe miRNAs expression according NPK availability, we observe that there is a gap about how these miRNAs are controlled. So, to find out what genes are activating or repressing these miRNAs, could help to complete the regulatory network involved in the sensing of plant nutrients.

Despite the quite large amount of data that can be found in the literature, it is clear that there is no standardization among experiments carried out with distinct nutrients by different research groups. These variations are much higher when experiments were performed with different plant species. As effective variables found in experiments, we observed: the developmental stage of the plants, the tissues types, the time kinetics of the stress, the nutrient concentrations to trigger the stress, and the methods to evaluate the effects on miRNA and target gene expressions. An effort should be made by the plant community of physiologists, biochemists, and molecular biologists in order to create models and patterns to evaluate in a more universal way the effects of nutrients and other agents in miRNAs and target gene expression.

\section{Acknowledgments}

This work was sponsored by a Productivity and Research Grant (307868/2011-7) from the National Council for Scientific and Technological Development (CNPq, Brazil). FK was sponsored by FAPERGS/CAPES-DOCFIX (1634-2551/13-9) grant.

and expression profiling during reproductive development and stress. BMC Genomics 8:242. doi: 10.1186/1471-2164-8-242

Aung, K., Lin, S. I., Wu, C. C., Huang, Y. T., Su, C. L., and Chiou, T. J. (2006). Pho2, a phosphate overaccumulator, is caused by a nonsense mutation in a microRNA399 target gene. Plant Physiol. 141, 1000-1011. doi: 10.1104/pp.106. 078063

Axtell, M. J., and Bowman, J. L. (2008). Evolution of plant microRNAs and their targets. Trends Plant Sci. 13, 343-349. doi: 10.1016/j.tplants.2008. 03.009 
Bari, R., Datt Pant, B., Stitt, M., and Scheible, W. R. (2006). PHO2, microRNA399, and PHR1 define a phosphate-signaling pathway in plants. Plant Physiol. 141, 988-999. doi: 10.1104/pp.106.079707

Barros-Carvalho, G. A., Paschoal, A. R., Marcelino-Guimaraes, F. C., and Hungria, M. (2014). Prediction of potential novel microRNAs in soybean when in symbiosis. Genet. Mol. Res. 13, 8519-8529. doi: 10.4238/2014.October.20.28

Bayle, V., Arrighi, J. F., Creff, A., Nespoulous, C., Vialaret, J., Rossignol, M., et al. (2011). Arabidopsis thaliana high-affinity phosphate transporters exhibit multiple levels of posttranslational regulation. Plant Cell 23, 1523-1535. doi: 10.1105/tpc. 110.081067

Bazin, J., Khan, G. A., Combier, J. P., Bustos-Sanmamed, P., Debernardi, J. M., Rodriguez, R., et al. (2013). miR396 affects mycorrhization and root meristem activity in the legume Medicago truncatula. Plant J. 74, 920-934. doi: $10.1111 /$ tpj.12178

Becker, A., and Theißen, G. (2003). The major clades of MADS-box genes and their role in the development and evolution of flowering plants. Mol. Phylogenet. Evol. 29, 464-489. doi: 10.1111/S1055-7903

Ben Amor, B., Wirth, S., Merchan, F., Laporte, P., D’aubenton-Carafa, Y., Hirsch, J., et al. (2009). Novel long non-protein coding RNAs involved in Arabidopsis differentiation and stress responses. Genome Res. 19, 57-69. doi: 10.1101/gr.080275.108

Bielewicz, D., Kalak, M., Kalyna, M., Windels, D., Barta, A., Vazquez, F., et al. (2013). Introns of plant pri-miRNAs enhance miRNA biogenesis. EMBO Rep. 14, 622-628. doi: 10.1038/embor.2013.62

Bose, J., Rodrigo-Moreno, A., Lai, D., Xie, Y., Shen, W., and Shabala, S. (2014a). Rapid regulation of the plasma membrane H+-ATPase activity is essential to salinity tolerance in two halophyte species, Atriplex lentiformis and Chenopodium quinoa. Ann. Bot. 115, 481-494. doi: 10.1093/aob/mcu219

Bose, J., Rodrigo-Moreno, A., and Shabala, S. (2014b). ROS homeostasis in halophytes in the context of salinity stress tolerance. J. Exp. Bot. 65, 1241-1257. doi: $10.1093 / \mathrm{jxb} / \mathrm{ert} 430$

Bose, J., Shabala, L., Pottosin, I., Zeng, F., Velarde-Buendia, A. M., Massart, A., et al. (2014c). Kinetics of xylem loading, membrane potential maintenance, and sensitivity of $\mathrm{K}^{+}$-permeable channels to reactive oxygen species: physiological traits that differentiate salinity tolerance between pea and barley. Plant Cell Environ. 37, 589-600. doi: 10.1111/pce.12180

Boualem, A., Laporte, P., Jovanovic, M., Laffont, C., Plet, J., Combier, J. P., et al. (2008). MicroRNA166 controls root and nodule development in Medicago truncatula. Plant J. 54, 876-887. doi: 10.1111/j.1365-313X.2008.0 3448.x

Branscheid, A., Sieh, D., Pant, B. D., May, P., Devers, E. A., Elkrog, A., et al. (2010). Expression pattern suggests a role of MiR399 in the regulation of the cellular response to local Pi increase during arbuscular mycorrhizal symbiosis. Mol. Plant Microbe Interact. 23, 915-926. doi: 10.1094/MPMI-23-7-0915

Buhtz, A., Pieritz, J., Springer, F., and Kehr, J. (2010). Phloem small RNAs, nutrient stress responses, and systemic mobility. BMC Plant Biol. 10:64. doi: 10.1186/1471-2229-10-64

Buhtz, A., Springer, F., Chappell, L., Baulcombe, D. C., and Kehr, J. (2008). Identification and characterization of small RNAs from the phloem of Brassica napus. Plant J. 53, 739-749. doi: 10.1111/j.1365-313X.2007.03368.x

Cai, H., Lu, Y., Xie, W., Zhu, T., and Lian, X. (2012). Transcriptome response to nitrogen starvation in rice. J. Biosci. 37, 731-747. doi: 10.1007/s12038-0129242-2

Chardon, F., Barthélémy, J., Daniel-Vedele, F., and Masclaux-Daubresse, C. (2010). Natural variation of nitrate uptake and nitrogen use efficiency in Arabidopsis thaliana cultivated with limiting and ample nitrogen supply. J. Exp. Bot. 61, 2293-2302. doi: 10.1093/jxb/erq059

Chen, X. M. (2004). A microRNA as a translational repressor of APETALA2 in Arabidopsis flower development. Science 303, 2022-2025. doi: 10.1126/science. 1088060

Chen, Y. F., Wang, Y., and Wu, W. H. (2008). Membrane transporters for nitrogen, phosphate and potassium uptake in plants. J. Integr. Plant Biol. 50, 835-848. doi: 10.1111/j.1744-7909.2008.00707.x

Cherel, I., Lefoulon, C., Boeglin, M., and Sentenac, H. (2014). Molecular mechanisms involved in plant adaptation to low $\mathrm{K}(+)$ availability. J. Exp. Bot. 65, 833-848. doi: 10.1093/jxb/ert402

Chiou, T. J., Aung, K., Lin, S. I., Wu, C. C., Chiang, S. F., and Su, C. L. (2006). Regulation of phosphate homeostasis by microRNA in Arabidopsis. Plant Cell 18, 412-421. doi: 10.1105/tpc.105.038943
Combier, J. P., Frugier, F., De Billy, F., Boualem, A., El-Yahyaoui, F., Moreau, S., et al. (2006). MtHAP2-1 is a key transcriptional regulator of symbiotic nodule development regulated by microRNA169 in Medicago truncatula. Genes Dev. 20, 3084-3088. doi: 10.1101/gad.402806

Creasey, K. M., Zhai, J., Borges, F., Van Ex, F., Regulski, M., Meyers, B. C., et al. (2014). miRNAs trigger widespread epigenetically activated siRNAs from transposons in Arabidopsis. Nature 508, 411-415. doi: 10.1038/nature13069

Cuperus, J. C., Fahlgren, N., and Carrington, J. (2011). Evolution and functional diversitfication of MIRNA genes. Plant Cell 23, 431-442. doi: $10.1105 /$ tpc. 110.082784

Daras, G., Rigas, S., Tsitsekian, D., Iacovides, T. A., and Hatzopoulos, P. (2015). Potassium transporter TRH1 subunits assemble regulating root-hair elongation autonomously from the cell fate determination pathway. Plant Sci. 231, 131137. doi: 10.1016/j.plantsci.2014.11.017

Delaux, P. M., Sejalon-Delmas, N., Becard, G., and Ane, J. M. (2013). Evolution of the plant-microbe symbiotic 'toolkit.' Trends Plant Sci. 18, 298-304. doi: 10.1016/j.tplants.2013.01.008

de Lima, J. C., Loss-Morais, G., and Margis, R. (2012). MicroRNAs play critical roles during plant development and in response to abiotic stresses. Genet Mol. Biol. 35, 1069-1077. doi: 10.1590/S1415-47572012000600023

De Luis, A., Markmann, K., Cognat, V., Holt, D. B., Charpentier, M., Parniske, M., et al. (2012). Two microRNAs linked to nodule infection and nitrogen-fixing ability in the legume Lotus japonicus. Plant Physiol. 160, 2137-2154. doi: 10.1104/pp.112.204883

Demidchik, V., Straltsova, D., Medvedev, S. S., Pozhvanov, G. A., Sokolik, A., and Yurin, V. (2014). Stress-induced electrolyte leakage: the role of K+-permeable channels and involvement in programmed cell death and metabolic adjustment. J. Exp. Bot. 65, 1259-1270. doi: 10.1093/jxb/eru004

Devers, E. A., Branscheid, A., May, P., and Krajinski, F. (2011). Stars and symbiosis: microRNA- and microRNA*-mediated transcript cleavage involved in arbuscular mycorrhizal symbiosis. Plant Physiol. 156, 1990-2010. doi: $10.1104 /$ pp.111.172627

Fahlgren, N., Jogdeo, S., Kasschau, K. D., Sullivan, C. M., Chapman, E. J., Laubinger, S., et al. (2010). MicroRNA gene evolution in Arabidopsis lyrata and Arabidopsis thaliana. Plant Cell 22, 1074-1089. doi: 10.1105/tpc.110. 073999

Fei, Q., Xia, R., and Meyers, B. C. (2013). Phased, secondary, small interfering RNAs in posttranscriptional regulatory networks. Plant Cell 25, 2400-2415. doi: 10.1105/tpc.113.114652

Finnegan, E. J., Margis, R., and Waterhouse, P. M. (2003). Posttranscriptional gene silencing is not compromised in the Arabidopsis CARPEL FACTORY (DICERLIKE1) mutant, a homolog of Dicer-1 from Drosophila. Curr. Biol. 13, 236-240. doi: 10.1016/S0960-9822(03)00010-1

Fischer, J. J., Beatty, P. H., Good, A. G., and Muench, D. G. (2013). Manipulation of microRNA expression to improve nitrogen use efficiency. Plant Sci. 210, 70-81. doi: 10.1016/j.plantsci.2013.05.009

Franco-Zorrilla, J. M., Valli, A., Todesco, M., Mateos, I., Puga, M. I., RubioSomoza, I., et al. (2007). Target mimicry provides a new mechanism for regulation of microRNA activity. Nat. Genet. 39, 1033-1037. doi: $10.1038 /$ ng2079

Frink, C. R., Waggoner, P. E., and Ausubel, J. H. (1999). Nitrogen fertilizer: retrospect and prospect. Proc. Natl. Acad. Sci. U.S.A. 96, 1175-1180. doi: 10.1073/pnas.96.4.1175

Fujii, H., Chiou, T. J., Lin, S. I., Aung, K., and Zhu, J. K. (2005). A miRNA involved in phosphate-starvation response in Arabidopsis. Curr. Biol. 15, 2038-2043. doi: 10.1016/j.cub.2005.10.016

Gifford, M. L., Dean, A., Gutierrez, R. A., Coruzzi, G. M., and Birnbaum, K. D. (2008). Cell-specific nitrogen responses mediate developmental plasticity. Proc. Natl. Acad. Sci. U.S.A. 105, 803-808. doi: 10.1073/pnas.07095 59105

Gonzalez, E., Solano, R., Rubio, V., Leyva, A., and Paz-Ares, J. (2005). PHOSPHATE TRANSPORTER TRAFFIC FACILITATOR1 is a plant-specific SEC12-related protein that enables the endoplasmic reticulum exit of a highaffinity phosphate transporter in Arabidopsis. Plant Cell 17, 3500-3512. doi: 10.1105/tpc. 105.036640

Good, A. G., and Beatty, P. H. (2011). Fertilizing nature: a tragedy of excess in the commons. PLoS Biol. 9:e1001124. doi: 10.1371/journal.pbio.1001124

Good, A. G., Shrawat, A. K., and Muench, D. G. (2004). Can less yield more? Is reducing nutrient input into the environment compatible 
with maintaining crop production? Trends. Plant Sci. 9, 597-605. doi: 10.1016/j.tplants.2004.10.008

Gou, J. Y., Felippes, F. F., Liu, C. J., Weigel, D., and Wang, J. W. (2011). Negative regulation of anthocyanin biosynthesis in Arabidopsis by a miR156-targeted SPL transcription factor. Plant Cell 23, 1512-1522. doi: 10.1105/tpc.111.084525

Gregory, B. D., O'Malley, R. C., Lister, R., Urich, M. A., Tonti-Filippini, J., Chen, H., et al. (2008). A link between RNA metabolism and silencing affecting Arabidopsis development. Dev. Cell 14, 854-866. doi: 10.1016/j.devcel.2008.04.005

Griffiths-Jones, S., Grocock, R. J., Van Dongen, S., Bateman, A., and Enright, A. J. (2006). miRBase: microRNA sequences, targets and gene nomenclature. Nucleic Acids Res. 34, D140-D144. doi: 10.1093/nar/gkj112

Gu, M., Xu, K., Chen, A., Zhu, Y., Tang, G., and Xu, G. (2010). Expression analysis suggests potential roles of microRNAs for phosphate and arbuscular mycorrhizal signaling in Solanum lycopersicum. Physiol. Plant. 138, 226-237. doi: 10.1111/j.1399-3054.2009.01320.x

Gutierrez, L., Mongelard, G., Flokova, K., Pacurar, D. I., Novak, O., Staswick, P., et al. (2012). Auxin controls Arabidopsis adventitious root initiation by regulating jasmonic acid homeostasis. Plant Cell 24, 2515-2527. doi: 10.1105/tpc.112.099119

Hamburger, D., Rezzonico, E., Macdonald-Comber Petetot, J., Somerville, C., and Poirier, Y. (2002). Identification and characterization of the Arabidopsis PHO1 gene involved in phosphate loading to the xylem. Plant Cell 14, 889-902. doi: 10.1105/tpc.000745

He, H., Liang, G., Li, Y., Wang, F., and Yu, D. (2014). Two young MicroRNAs originating from target duplication mediate nitrogen starvation adaptation via regulation of glucosinolate synthesis in Arabidopsis thaliana. Plant Physiol. 164, 853-865. doi: 10.1104/pp.113.228635

Hirel, B., Le Gouis, J., Ney, B., and Gallais, A. (2007). The challenge of improving nitrogen use efficiency in crop plants: towards a more central role for genetic variability and quantitative genetics within integrated approaches. J. Exp. Bot. 58, 2369-2387. doi: 10.1093/jxb/erm097

Hsieh, L. C., Lin, S. I., Shih, A. C., Chen, J. W., Lin, W. Y., Tseng, C. Y., et al. (2009). Uncovering small RNA-mediated responses to phosphate deficiency in Arabidopsis by deep sequencing. Plant Physiol. 151, 2120-2132. doi: 10.1104/pp.109.147280

Huang, T. K., Han, C. L., Lin, S. I., Chen, Y. J., Tsai, Y. C., Chen, Y. R., et al. (2013). Identification of downstream components of ubiquitin-conjugating enzyme PHOSPHATE2 by quantitative membrane proteomics in Arabidopsis roots. Plant Cell 25, 4044-4060. doi: 10.1105/tpc.113.115998

Jacobsen, S. E., Running, M. P., and Meyerowitz, E. M. (1999). Disruption of an RNA helicase/RNAse III gene in Arabidopsis causes unregulated cell division in floral meristems. Development 126, 5231-5243.

Janczarek, M., Rachwal, K., Marzec, A., Grzadziel, J., and Palusinska-Szysz, M. (2015). Signal molecules and cell-surface components involved in early stages of the legume-rhizobium interactions. Appl. Soil Ecol. 85, 94-113. doi: 10.1016/j.apsoil.2014.08.010

Jeong, D. H., and Green, P. J. (2013). The role of rice microRNAs in abiotic stress responses. J. Plant Biol. 56, 187-197. doi: 10.1007/s12374-0130213-4

Jeong, D. H., Park, S., Zhai, J., Gurazada, S. G., De Paoli, E., Meyers, B. C., et al. (2011). Massive analysis of rice small RNAs: mechanistic implications of regulated microRNAs and variants for differential target RNA cleavage. Plant Cell 23, 4185-4207. doi: 10.1105/tpc.111.089045

Jones-Rhoades, M. W., and Bartel, D. P. (2004). Computational identification of plant microRNAs and their targets, including a stress-induced miRNA. Mol. Cell. 14, 787-799. doi: 10.1016/j.molcel.2004.05.027

Joshi, T., Yan, Z., Libault, M., Jeong, D. H., Park, S., Green, P. J., et al. (2010). Prediction of novel miRNAs and associated target genes in Glycine max. BMC Bioinform. 11(Suppl. 1):S14. doi: 10.1186/1471-2105-11S1-S14

Kant, S., Peng, M., and Rothstein, S. J. (2011). Genetic regulation by NLA and microRNA827 for maintaining nitrate-dependent phosphate homeostasis in Arabidopsis. PLoS Genet. 7:e1002021. doi: 10.1371/journal.pgen.10 02021

Karthikeyan, A. S., Varadarajan, D. K., Mukatira, U. T., D'Urzo, M. P., Damsz, B., and Raghothama, K. G. (2002). Regulated expression of Arabidopsis phosphate transporters. Plant Physiol. 130, 221-233. doi: 10.1104/pp.0 20007
Kehr, J. (2013). Systemic regulation of mineral homeostasis by microRNAs. Front. Plant Sci. 4:145. doi: 10.3389/fpls.2013.00145

Kim, S., Yang, J. Y., Xu, J., Jang, I. C., Prigge, M. J., and Chua, N. H. (2008). Two cap-binding proteins CBP20 and CBP80 are involved in processing primary microRNAs. Plant Cell Physiol. 49, 1634-1644. doi: 10.1093/pcp/ pcn 146

Krapp, A., Berthome, R., Orsel, M., Mercey-Boutet, S., Yu, A., Castaings, L., et al. (2012). Arabidopsis roots and shoots show distinct temporal adaptation patterns toward nitrogen starvation. Plant Physiol. 157, 1255-1282. doi: 10.1104/pp.111.179838

Kulcheski, F. R., De Oliveira, L. F., Molina, L. G., Almerao, M. P., Rodrigues, F. A. Marcolino, J., et al. (2011). Identification of novel soybean microRNAs involved in abiotic and biotic stresses. BMC Genomics 12:307. doi: 10.1186/1471-216412-307

Kumar, R. (2014). Role of microRNAs in biotic and abiotic stress responses in crop plants. Appl. Biochem. Biotechnol. 174, 93-115. doi: 10.1007/s12010-01431050914-2

Kuo, H. F., and Chiou, T. J. (2011). The role of microRNAs in phosphorus deficiency signaling. Plant Physiol. 156, 1016-1024. doi: 10.1104/pp.111.175265

Kutchan, T. M. (1995). Alkaloid biosynthesis[mdash]the basis for metabolic engineering of medicinal plants. Plant Cell 7, 1059-1070. doi: 10.1105/tpc.7.7.1059

Laubinger, S., Sachsenberg, T., Zeller, G., Busch, W., Lohmann, J. U., Ratsch, G., et al. (2008). Dual roles of the nuclear cap-binding complex and SERRATE in pre-mRNA splicing and microRNA processing in Arabidopsis thaliana. Proc. Natl. Acad. Sci. U.S.A. 105, 8795-8800. doi: 10.1073/pnas.08024 93105

Lauressergues, D., Delaux, P. M., Formey, D., Lelandais-Briere, C., Fort, S., Cottaz, S., et al. (2012). The microRNA miR171h modulates arbuscular mycorrhizal colonization of Medicago truncatula by targeting NSP2. Plant J. 72, 512-522. doi: 10.1111/j.1365-313X.2012.05099.x

Lee, S., Kim, J., Son, J. S., Nam, J., Jeong, D. H., Lee, K., et al. (2003). Systematic reverse genetic screening of T-DNA tagged genes in rice for functional genomic analyses: MADS-box genes as a test case. Plant Cell Physiol. 44, 1403-1411. doi: $10.1093 / \mathrm{pcp} / \mathrm{pcg} 156$

Lelandais-Briere, C., Naya, L., Sallet, E., Calenge, F., Frugier, F., Hartmann, C., et al. (2009). Genome-wide Medicago truncatula small RNA analysis revealed novel microRNAs and isoforms differentially regulated in roots and nodules. Plant Cell 21, 2780-2796. doi: 10.1105/tpc.109.068130

Li, H., Deng, Y., Wu, T., Subramanian, S., and Yu, O. (2010a). Misexpression of miR482, miR1512, and miR1515 increases soybean nodulation. Plant Physiol. 153, 1759-1770. doi: 10.1104/pp.110.156950

Li, Y. F., Zheng, Y., Addo-Quaye, C., Zhang, L., Saini, A., Jagadeeswaran, G., et al. (2010b). Transcriptome-wide identification of microRNA targets in rice. Plant J. 62, 742-759. doi: 10.1111/j.1365-313X.2010.04187.x

Li, S. S., Ran, Y. J., Zhang, D. D., Li, S. Z., and Zhu, D. (2014). MicroRNA-190 regulates hypoxic pulmonary vasoconstriction by targeting a voltage-gated $\mathrm{K}^{+}$ channel in arterial smooth muscle cells. J. Cell. Biochem. 115, 1196-1205. doi: $10.1002 /$ jcb. 24771

Li, W. X., Oono, Y., Zhu, J., He, X. J., Wu, J. M., Iida, K., et al. (2008). The Arabidopsis NFYA5 transcription factor is regulated transcriptionally and posttranscriptionally to promote drought resistance. Plant Cell 20, 2238-2251. doi: 10.1105/tpc.108.059444

Li, Y., Yang, C. M., Xi, Y., Wu, G., Shelat, H., Gao, S., et al. (2013). MicroRNA-1/133 targeted dysfunction of potassium channels KCNE1 and KCNQ1 in human cardiac progenitor cells with simulated hyperglycemia. Int. J. Cardiol. 167, 1076-1078. doi: 10.1016/j.ijcard.2012.10.060

Liang, G., He, H., and Yu, D. (2012). Identification of nitrogen starvationresponsive microRNAs in Arabidopsis thaliana. PLoS ONE 7:e48951. doi: 10.1371/journal.pone.0048951

Lin, S. I., Chiang, S. F., Lin, W. Y., Chen, J. W., Tseng, C. Y., Wu, P. C., et al. (2008). Regulatory network of microRNA399 and PHO2 by systemic signaling. Plant Physiol. 147, 732-746. doi: 10.1104/pp.108.116269

Lin, S. I., Santi, C., Jobet, E., Lacut, E., El Kholti, N., Karlowski, W. M., et al. (2010). Complex regulation of two target genes encoding SPX-MFS proteins by rice miR827 in response to phosphate starvation. Plant Cell Physiol. 51, 2119-2131. doi: $10.1093 / \mathrm{pcp} / \mathrm{pcq} 170$

Lin, W. Y., Huang, T. K., and Chiou, T. J. (2013). Nitrogen limitation adaptation, a target of microRNA827, mediates degradation of plasma membrane-localized 
phosphate transporters to maintain phosphate homeostasis in Arabidopsis. Plant Cell 25, 4061-4074. doi: 10.1105/tpc.113.116012

Liu, T. Y., Huang, T. K., Tseng, C. Y., Lai, Y. S., Lin, S. I., Lin, W. Y., et al. (2012). PHO2-dependent degradation of PHO1 modulates phosphate homeostasis in Arabidopsis. Plant Cell 24, 2168-2183. doi: 10.1105/tpc.112.096636

Lopez-Bucio, J., Cruz-Ramirez, A., and Herrera-Estrella, L. (2003). The role of nutrient availability in regulating root architecture. Curr. Opin. Plant Biol. 6, 280-287. doi: 10.1016/S1369-5266(03)00035-9

Lu, C., and Fedoroff, N. (2000). A mutation in the Arabidopsis HYL1 gene encoding a dsRNA binding protein affects responses to abscisic acid, auxin, and cytokinin. Plant Cell 12, 2351-2366. doi: 10.1105/tpc.12.12.2351

Lu, C., Jeong, D. H., Kulkarni, K., Pillay, M., Nobuta, K., German, R., et al. (2008). Genome-wide analysis for discovery of rice microRNAs reveals natural antisense microRNAs (nat-miRNAs). Proc. Natl. Acad. Sci. U.S.A. 105, 49514956. doi: $10.1073 /$ pnas. 0708743105

Lundmark, M., Korner, C. J., and Nielsen, T. H. (2010). Global analysis of microRNA in Arabidopsis in response to phosphate starvation as studied by locked nucleic acid-based microarrays. Physiol. Plant. 140, 57-68. doi: 10.1111/j.1399-3054.2010.01384.x

MacLean, D., Elina, N., Havecker, E. R., Heimstaedt, S. B., Studholme, D. J., and Baulcombe, D. C. (2010). Evidence for large complex networks of plant short silencing RNAs. PLoS ONE 5:e9901. doi: 10.1371/journal.pone.00 09901

Manavella, P. A., Hagmann, J., Ott, F., Laubinger, S., Franz, M., Macek, B., et al. (2012). Fast-forward genetics identifies plant CPL phosphatases as regulators of miRNA processing factor HYL1. Cell 151, 859-870. doi: 10.1016/j.cell.2012.09.039

Margis, R., Fusaro, A. F., Smith, N. A., Curtin, S. J., Watson, J. M., Finnegan, E. J., et al. (2006). The evolution and diversification of Dicers in plants. FEBS Lett. 580, 2442-2450. doi: 10.1016/j.febslet.2006.03.072

Masclaux-Daubresse, C., Reisdorf-Cren, M., and Orsel, M. (2008). Leaf nitrogen remobilisation for plant development and grain filling. Plant Biol. 10, 23-36. doi: $10.1111 / j .1438-8677.2008 .00097$

Masson-Boivin, C., Giraud, E., Perret, X., and Batut, J. (2009). Establishing nitrogen-fixing symbiosis with legumes: how many rhizobium recipes? Trends Microbiol. 17, 458-466. doi: 10.1016/j.tim.2009.07.004

Matts, J., Jagadeeswaran, G., Roe, B. A., and Sunkar, R. (2010). Identification of microRNAs and their targets in switchgrass, a model biofuel plant species. J. Plant Physiol. 167, 896-904. doi: 10.1016/j.jplph.2010.02.001

Megraw, M., Baev, V., Rusinov, V., Jensen, S. T., Kalantidis, K., and Hatzigeorgiou, A. G. (2006). MicroRNA promoter element discovery in Arabidopsis. RNA 12, 1612-1619. doi: 10.1261/rna.130506

Montzka, S. A., Dlugokencky, E. J., and Butler, J. H. (2011). Non-CO2 greenhouse gases and climate change. Nature 476, 43-50. doi: 10.1038/nature10322

Morel, J. B., Godon, C., Mourrain, P., Beclin, C., Boutet, S., Feuerbach, F., et al. (2002). Fertile hypomorphic ARGONAUTE (ago1) mutants impaired in posttranscriptional gene silencing and virus resistance. Plant Cell 14, 629-639. doi: 10.1105/tpc.010358

Mudge, S. R., Rae, A. L., Diatloff, E., and Smith, F. W. (2002). Expression analysis suggests novel roles for members of the Pht 1 family of phosphate transporters in Arabidopsis. Plant J. 31, 341-353. doi: 10.1046/j.1365-313X.2002.01356.x

Murray, J. D. (2011). Invasion by invitation: rhizobial infection in legumes. Mol. Plant Microbe Interact. 24, 631-639. doi: 10.1094/MPMI-08-10-0181

Nischal, L., Mohsin, M., Khan, I., Kardam, H., Wadhwa, A., Abrol, Y. P., et al. (2012). Identification and comparative analysis of microRNAs associated with low-N tolerance in rice genotypes. PLOS ONE 7:e50261. doi: 10.1371/journal.pone.0050261

Nodine, M. D., and Bartel, D. P. (2010). MicroRNAs prevent precocious gene expression and enable pattern formation during plant embryogenesis. Genes Dev. 24, 2678-2692. doi: 10.1101/gad.1986710

Nogueira, F. T., Madi, S., Chitwood, D. H., Juarez, M. T., and Timmermans, M. C. (2007). Two small regulatory RNAs establish opposing fates of a developmental axis. Genes Dev. 21, 750-755. doi: 10.1101/gad.1528607

Okumura, S., Mitsukawa, N., Shirano, Y., and Shibata, D. (1998). Phosphate transporter gene family of Arabidopsis thaliana. DNA Res. 5, 261-269. doi: 10.1093/dnares/5.5.261

Pant, B. D., Buhtz, A., Kehr, J., and Scheible, W. R. (2008). MicroRNA399 is a longdistance signal for the regulation of plant phosphate homeostasis. Plant J. 53, 731-738. doi: 10.1111/j.1365-313X.2007.03363.x
Pant, B. D., Musialak-Lange, M., Nuc, P., May, P., Buhtz, A., Kehr, J., et al. (2009). Identification of nutrient-responsive Arabidopsis and rapeseed microRNAs by comprehensive real-time polymerase chain reaction profiling and small RNA sequencing. Plant Physiol. 150, 1541-1555. doi: 10.1104/pp.109.139139

Park, B. S., Seo, J. S., and Chua, N. H. (2014). NITROGEN LIMITATION ADAPTATION recruits PHOSPHATE2 to target the phosphate transporter PT2 for degradation during the regulation of Arabidopsis phosphate homeostasis. Plant Cell 26, 454-464. doi: 10.1105/tpc.113.120311

Park, M. Y., Wu, G., Gonzalez-Sulser, A., Vaucheret, H., and Poethig, R. S. (2005). Nuclear processing and export of microRNAs in Arabidopsis. Proc. Natl. Acad. Sci. U.S.A. 102, 3691-3696. doi: 10.1073/pnas. 0405570102

Peragine, A., Yoshikawa, M., Wu, G., Albrecht, H. L., and Poethig, R. S. (2004). SGS3 and SGS2/SDE1/RDR6 are required for juvenile development and the production of trans-acting siRNAs in Arabidopsis. Genes Dev. 18, 2368-2379. doi: $10.1101 / \mathrm{gad} .1231804$

Poirier, Y., Thoma, S., Somerville, C., and Schiefelbein, J. (1991). Mutant of Arabidopsis deficient in xylem loading of phosphate. Plant Physiol. 97, 10871093. doi: $10.1104 /$ pp.97.3.1087

Poulsen, C., Vaucheret, H., and Brodersen, P. (2013). Lessons on RNA silencing mechanisms in plants from eukaryotic argonaute structures. Plant Cell 25, 22-37. doi: 10.1105/tpc.112.105643

Radwanski, E. R., and Last, R. L. (1995). Tryptophan biosynthesis and metabolism: biochemical and molecular genetics. Plant Cell 7, 921-934. doi: 10.1105/tpc.7.7.921

Raghothama, K. G. (1999). Phosphate acquisition. Annu. Rev. Plant Physiol. Plant Mol. Biol. 50, 665-693. doi: 10.1146/annurev.arplant.50.1.665

Rajagopalan, R., Vaucheret, H., Trejo, J., and Bartel, D. P. (2006). A diverse and evolutionarily fluid set of microRNAs in Arabidopsis thaliana. Genes Dev. 20, 3407-3425. doi: 10.1101/gad.1476406

Ramachandran, V., and Chen, X. (2008). Degradation of microRNAs by a family of exoribonucleases in Arabidopsis. Science 321, 1490-1492. doi: 10.1126/science. 1163728

Reinhart, B. J., Weinstein, E. G., Rhoades, M. W., Bartel, B., and Bartel, D. P. (2002). MicroRNAs in plants. Genes Dev. 16, 1616-1626. doi: 10.1101/gad.10 04402

Ren, G., Xie, M., Dou, Y., Zhang, S., Zhang, C., and Yu, B. (2012). Regulation of miRNA abundance by RNA binding protein TOUGH in Arabidopsis. Proc. Natl. Acad. Sci. U.S.A. 109, 12817-12821. doi: 10.1073/pnas.1204915109

Ren, Y., Sun, F., Hou, J., Chen, L., Zhang, Y., Kang, X., et al. (2015). Differential profiling analysis of miRNAs reveals a regulatory role in low $\mathrm{N}$ stress response of Populus. Funct. Integr. Genomics 15, 93-105. doi: 10.1007/s10142-014-0408-x

Rhoades, M. W., Reinhart, B. J., Lim, L. P., Burge, C. B., Bartel, B., and Bartel, D. P. (2002). Prediction of plant microRNA targets. Cell 110, 513-520. doi: 10.1016/S0092-8674(02)00863-2

Rogers, K., and Chen, X. (2013). Biogenesis, turnover, and mode of action of plant microRNAs. Plant Cell 25, 2383-2399. doi: 10.1105/tpc.113.113159

Sarkies, P., and Miska, E. A. (2014). Small RNAs break out: the molecular cell biology of mobile small RNAs. Nat. Rev. Mol. Cell Biol. 15, 525-535. doi: $10.1038 / \mathrm{nrm} 3840$

Schachtman, D. P. (2000). Molecular insights into the structure and function of plant $\mathrm{K}^{+}$transport mechanisms. Biochim. Biophys. Acta 1465, 127-139. doi: 10.1016/S0005-2736(00)00134-6

Schroeder, J. I., Ward, J. M., and Gassmann, W. (1994). Perspectives on the physiology and structure of inward-rectifying $\mathrm{K}^{+}$channels in higher plants: biophysical implications for $\mathrm{K}^{+}$uptake. Annu. Rev. Biophys. Biomol. Struct. 23, 441-471. doi: 10.1146/annurev.bb.23.060194.002301

Simon, S. A., Meyers, B. C., and Sherrier, D. J. (2009). MicroRNAs in the rhizobia legume symbiosis. Plant Physiol. 151, 1002-1008. doi: 10.1104/pp.109.144345

Straltsova, D., Chykun, P., Subramaniam, S., Sosan, A., Kolbanov, D., Sokolik, A., et al. (2014). Cation channels are involved in brassinosteroid signalling in higher plants. Steroids 97, 98-106. doi: 10.1016/j.steroids.2014.10.008

Subramanian, S., Fu, Y., Sunkar, R., Barbazuk, W. B., Zhu, J. K., and Yu, O. (2008). Novel and nodulation-regulated microRNAs in soybean roots. BMC Genomics 9:160. doi: 10.1186/1471-2164-9-160

Sunkar, R., Girke, T., Jain, P. K., and Zhu, J. K. (2005). Cloning and characterization of microRNAs from rice. Plant Cell 17, 1397-1411. doi: 10.1105/tpc.105.031682

Sunkar, R., Li, Y. F., and Jagadeeswaran, G. (2012). Functions of microRNAs in plant stress responses. Trends Plant Sci. 17, 196-203. doi: 10.1016/j.tplants.2012.01.010 
Tatro, E. T., Hefler, S., Shumaker-Armstrong, S., Soontornniyomkij, B., Yang, M., Yermanos, A., et al. (2013). Modulation of BK channel by MicroRNA-9 in neurons after exposure to HIV and methamphetamine. J. Neuroimmune Pharmacol. 8, 1210-1223. doi: 10.1007/s11481-013-9446-8

ten Hoopen, F., Cuin, T. A., Pedas, P., Hegelund, J. N., Shabala, S., Schjoerring, J. K., et al. (2010). Competition between uptake of ammonium and potassium in barley and Arabidopsis roots: molecular mechanisms and physiological consequences. J. Exp. Bot. 61, 2303-2315. doi: 10.1093/jxb/ erq057

Todesco, M., Rubio-Somoza, I., Paz-Ares, J., and Weigel, D. (2010). A collection of target mimics for comprehensive analysis of microRNA function in Arabidopsis thaliana. PLoS Genet. 6:e1001031. doi: 10.1371/journal.pgen.10 01031

Trevisan, S., Begheldo, M., Nonis, A., and Quaggiotti, S. (2012a). The miRNAmediated post-transcriptional regulation of maize response to nitrate. Plant Signal. Behav. 7, 822-826. doi: 10.4161/psb.20462

Trevisan, S., Nonis, A., Begheldo, M., Manoli, A., Palme, K., Caporale, G., et al. (2012b). Expression and tissue-specific localization of nitrate-responsive miRNAs in roots of maize seedlings. Plant Cell Environ. 35, 1137-1155. doi: 10.1111/j.1365-3040.2011.02478.x

Turner, M., Nizampatnam, N. R., Baron, M., Coppin, S., Damodaran, S., Adhikari, S., et al. (2013). Ectopic expression of miR160 results in auxin hypersensitivity, cytokinin hyposensitivity, and inhibition of symbiotic nodule development in soybean. Plant Physiol. 162, 2042-2055. doi: 10.1104/pp.113.220699

Valdés-López, O., Yang, S. S., Aparicio-Fabre, R., Graham, P. H., Reyes, J. L., Vance, C. P., et al. (2010). icroRNA expression profile in common bean (Phaseolus vulgaris) under nutrient deficiency stresses and manganese toxicity. New Phytol. 187, 805-818. doi: 10.1111/j.1469-8137.2010.03320.x

Vazquez, F., Blevins, T., Ailhas, J., Boller, T., and Meins, F. Jr. (2008). Evolution of Arabidopsis MIR genes generates novel microRNA classes. Nucleic Acids Res. 36, 6429-6438. doi: 10.1093/nar/gkn670

Vidal, E. A., Araus, V., Lu, C., Parry, G., Green, P. J., Coruzzi, G. M., et al. (2010). Nitrate-responsive miR393/AFB3 regulatory module controls root system architecture in Arabidopsis thaliana. Proc. Natl. Acad. Sci. U.S.A. 107, 4477-4482. doi: 10.1073/pnas.0909571107

Vidal, E. A., Moyano, T. C., Krouk, G., Katari, M. S., Tanurdzic, M., Mccombie, W. R., et al. (2013). Integrated RNA-seq and sRNA-seq analysis identifies novel nitrate-responsive genes in Arabidopsis thaliana roots. BMC Genomics 14:701. doi: 10.1186/1471-2164-14-701

Voinnet, O. (2009). Origin, biogenesis, and activity of plant microRNAs. Cell 136, 669-687. doi: 10.1016/j.cell.2009.01.046

Wang, C., Huang, W., Ying, Y., Li, S., Secco, D., Tyerman, S., et al. (2012). Functional characterization of the rice SPX-MFS family reveals a key role of OsSPX-MFS1 in controlling phosphate homeostasis in leaves. New Phytol. 196, 139-148. doi: 10.1111/j.1469-8137.2012.04227.x

Wang, J. W., Czech, B., and Weigel, D. (2009a). miR156-regulated SPL transcription factors define an endogenous flowering pathway in Arabidopsis thaliana. Cell 138, 738-749. doi: 10.1016/j.cell.2009.06.014

Wang, Y., Li, P., Cao, X., Wang, X., Zhang, A., and Li, X. (2009b). Identification and expression analysis of miRNAs from nitrogen-fixing soybean nodules. Biochem. Biophys. Res. Commun. 378, 799-803. doi: 10.1016/j.bbrc.2008.11.140

Wang, J. W., Wang, L. J., Mao, Y. B., Cai, W. J., Xue, H. W., and Chen, X. Y. (2005) Control of root cap formation by MicroRNA-targeted auxin response factors in Arabidopsis. Plant Cell 17, 2204-2216. doi: 10.1105/tpc.105.033076

Wang, L., Mai, Y. X., Zhang, Y. C., Luo, Q., and Yang, H. Q. (2010). MicroRNA171c-targeted SCL6-II, SCL6-III, and SCL6-IV genes regulate shoot branching in Arabidopsis. Mol. Plant 3, 794-806. doi: 10.1093/mp/ ssq042

Wang, Y., Wang, L., Zou, Y., Chen, L., Cai, Z., Zhang, S., et al. (2014a). Soybean miR172c targets the repressive AP2 transcription factor NNC1 to activate ENOD40 expression and regulate nodule initiation. Plant Cell 26, 4782-4801. doi: $10.1105 /$ tpc.114.131607

Wang, Y., Wang, Z., Amyot, L., Tian, L., Xu, Z., Gruber, M. Y., et al. (2014b) Ectopic expression of miR156 represses nodulation and causes morphological and developmental changes in Lotus japonicus. Mol. Genet. Genomics. 290, 471-484. doi: 10.1007/s00438-014-0931-4

Wang, Y., Zhang, C., Hao, Q., Sha, A., Zhou, R., Zhou, X., et al. (2013). Elucidation of miRNAs-mediated responses to low nitrogen stress by deep sequencing of two soybean genotypes. PLoS ONE 8:e67423. doi: 10.1371/journal.pone.0067423

Wenkel, S., Turck, F., Singer, K., Gissot, L., Le Gourrierec, J., Samach, A., et al. (2006). CONSTANS and the CCAAT Box Binding Complex share a functionally important domain and interact to regulate flowering of Arabidopsis. Plant Cell 18, 2971-2984. doi: 10.1105/tpc.106.043299

Williams, L., and Miller, A. (2001). Transporters responsible for the uptake and partitioning of nitrogenous solutes. Annu. Rev. Plant Physiol. Plant Mol. Biol. 52, 659-688. doi: 10.1146/annurev.arplant.52.1.659

Willmann, M. R., and Poethig, R. S. (2007). Conservation and evolution of miRNA regulatory programs in plant development. Curr. Opin. Plant Biol 10, 503-511. doi: 10.1016/j.pbi.2007.07.004

Wu, G., Park, M. Y., Conway, S. R., Wang, J. W., Weigel, D., and Poethig, R. S. (2009a). The sequential action of miR156 and miR172 regulates developmental timing in Arabidopsis. Cell 138, 750-759. doi: 10.1016/j.cell.2009. 06.031

Wu, L., Zhang, Q., Zhou, H., Ni, F., Wu, X., and Qi, Y. (2009b). Rice MicroRNA effector complexes and targets. Plant Cell 21, 3421-3435. doi: 10.1105/tpc.109.070938

Wu, X., Shi, Y., Li, J., Xu, L., Fang, Y., Li, X., et al. (2013). A role for the RNAbinding protein MOS2 in microRNA maturation in Arabidopsis. Cell Res. 23, 645-657. doi: 10.1038/cr.2013.23

Xie, Z., Allen, E., Fahlgren, N., Calamar, A., Givan, S. A., and Carrington, J. C. (2005). Expression of Arabidopsis MIRNA genes. Plant Physiol. 138, 2145-2154. doi: $10.1104 /$ pp.105.062943

Xie, Z., Johansen, L. K., Gustafson, A. M., Kasschau, K. D., Lellis, A. D. Zilberman, D., et al. (2004). Genetic and functional diversification of small RNA pathways in plants. PLoS Biol. 2:e104. doi: 10.1371/journal.pbio.00 20104

Xing, S., Salinas, M., Hohmann, S., Berndtgen, R., and Huijser, P. (2010). miR156-targeted and nontargeted SBP-box transcription factors act in concert to secure male fertility in Arabidopsis. Plant Cell 22:3935-3950. doi: 10.1105/tpc.110.079343

Xu, X., Bai, H., Liu, C., Chen, E., Chen, Q., Zhuang, J., et al. (2014). Genome-wide analysis of microRNAs and their target genes related to leaf senescence of rice. PLOS ONE 9:e114313. doi: 10.1371/journal.pone.0114313

Xu, Z., Zhong, S., Li, X., Li, W., Rothstein, S. J., Zhang, S., et al. (2011). Genomewide identification of microRNAs in response to low nitrate availability in maize leaves and roots. PLoS ONE 6:e28009. doi: 10.1371/journal.pone.0028009

Yan, Y., Wang, H., Hamera, S., Chen, X., and Fang, R. (2014). miR444a has multiple functions in the rice nitrate-signaling pathway. Plant J. 78, 44-55. doi: 10.1111/tpj.12446

Yan, Z., Hossain, M. S., Wang, J., Valdes-Lopez, O., Liang, Y., Libault, M., et al. (2013). miR172 regulates soybean nodulation. Mol. Plant Microbe Interact. 26, 1371-1377. doi: 10.1094/MPMI-04-13-0111-R

Yang, L., Conway, S. R., and Poethig, R. S. (2011). Vegetative phase change is mediated by a leaf-derived signal that represses the transcription of miR156. Development 138, 245-249. doi: 10.1242/dev.058578

Yang, L., Liu, Z., Lu, F., Dong, A., and Huang, H. (2006). SERRATE is a novel nuclear regulator in primary microRNA processing in Arabidopsis. Plant J. 47, 841-850. doi: 10.1111/j.1365-313X.2006.02835.x

Yang, L., Xu, M., Koo, Y., He, J., and Poethig, R. S. (2013). Sugar promotes vegetative phase change in Arabidopsis thaliana by repressing the expression of MIR156A and MIR156C. Elife 2:e00260. doi: 10.7554/eLife. 00260

Yu, B., Bi, L., Zheng, B., Ji, L., Chevalier, D., Agarwal, M., et al. (2008). The FHA domain proteins DAWDLE in Arabidopsis and SNIP1 in humans act in small RNA biogenesis. Proc. Natl. Acad. Sci. U.S.A. 105, 10073-10078. doi: 10.1073/pnas.0804218105

Yu, B., Yang, Z., Li, J., Minakhina, S., Yang, M., Padgett, R. W., et al. (2005). Methylation as a crucial step in plant microRNA biogenesis. Science 307, 932-935. doi: 10.1126/science. 1107130

Yu, N., Cai, W. J., Wang, S., Shan, C. M., Wang, L. J., and Chen, X. Y. (2010). Temporal control of trichome distribution by microRNA156targeted SPL genes in Arabidopsis thaliana. Plant Cell 22, 2322-2335. doi: 10.1105/tpc.109.072579

Yu, S., Cao, L., Zhou, C. M., Zhang, T. Q., Lian, H., Sun, Y., et al. (2013). Sugar is an endogenous cue for juvenile-to-adult phase transition in plants. Elife 2:e00269. doi: $10.7554 /$ eLife.00269 
Zeng, H., Wang, G., Hu, X., Wang, H., Du, L., and Zhu, Y. (2014). Role of microRNAs in plant responses to nutrient stress. Plant Soil 374, 1005-1021. doi: 10.1007/s11104-013-1907-6

Zeng, H. Q., Zhu, Y. Y., Huang, S. Q., and Yang, Z. M. (2010). Analysis of phosphorus-deficient responsive miRNAs and cis-elements from soybean (Glycine max L.). J. Plant Physiol. 167, 1289-1297. doi: 10.1016/j.jplph.2010.04.017

Zhan, X., Wang, B., Li, H., Liu, R., Kalia, R. K., Zhu, J. K., et al. (2012). Arabidopsis proline-rich protein important for development and abiotic stress tolerance is involved in microRNA biogenesis. Proc. Natl. Acad. Sci. U.S.A. 109, 1819818203. doi: 10.1073/pnas.1216199109

Zhang, H., and Forde, B. G. (1998). An Arabidopsis MADS box gene that controls nutrient-induced changes in root architecture. Science 279, 407-409. doi: 10.1126/science. 279.5349 .407

Zhang, Q., Zhao, C., Li, M., Sun, W., Liu, Y., Xia, H., et al. (2013). Genome-wide identification of Thellungiella salsuginea microRNAs with putative roles in the salt stress response. BMC Plant Biol. 13:180. doi: 10.1186/1471-2229-13-180

Zhang, Y. M., Zhang, H. M., Liu, Z. H., Li, H. C., Guo, X. L., and Li, G. L. (2015). The wheat NHX antiporter gene TaNHX2 confers salt tolerance in transgenic alfalfa by increasing the retention capacity of intracellular potassium. Plant Mol. Biol. 87, 317-327. doi: 10.1007/s11103-014-0278-6

Zhao, J., Williams, C. C., and Last, R. L. (1998). Induction of Arabidopsis tryptophan pathway enzymes and camalexin by amino acid starvation, oxidative stress, and an abiotic elicitor. Plant Cell 10, 359-370. doi: $10.2307 / 3870594$

Zhao, M., Ding, H., Zhu, J. K., Zhang, F., and Li, W. X. (2011). Involvement of miR169 in the nitrogen-starvation responses in Arabidopsis. New Phytol. 190, 906-915. doi: 10.1111/j.1469-8137.2011.03647.x
Zhao, M., Tai, H., Sun, S., Zhang, F., Xu, Y., and Li, W. X. (2012). Cloning and characterization of maize miRNAs involved in responses to nitrogen deficiency. PLoS ONE 7:e29669. doi: 10.1371/journal.pone.0029669

Zhao, X., Zhang, H., and Li, L. (2013). Identification and analysis of the proximal promoters of microRNA genes in Arabidopsis. Genomics 101, 187-194. doi: 10.1016/j.ygeno.2012.12.004

Zhou, J., Jiao, F., Wu, Z., Li, Y., Wang, X., He, X., et al. (2008). OsPHR2 is involved in phosphate-starvation signaling and excessive phosphate accumulation in shoots of plants. Plant Physiol. 146, 1673-1686. doi: 10.1104/pp.107. 111443

Zhu, Y. Y., Zeng, H. Q., Dong, C. X., Yin, X. M., Shen, Q. R., and Yang, Z. M. (2010). MicroRNA expression profiles associated with phosphorus deficiency in white lupin (Lupinus albus L.). Plant Sci. 178, 23-29. doi: 10.1016/j.plantsci.2009.09.011

Zorb, C., Senbayram, M., and Peiter, E. (2014). Potassium in agriculture-status and perspectives. J. Plant Physiol. 171, 656-669. doi: 10.1016/j.jplph.2013.08.008

Conflict of Interest Statement: The authors declare that the research was conducted in the absence of any commercial or financial relationships that could be construed as a potential conflict of interest.

Copyright (c) 2015 Kulcheski, Côrrea, Gomes, de Lima and Margis. This is an openaccess article distributed under the terms of the Creative Commons Attribution License (CC BY). The use, distribution or reproduction in other forums is permitted, provided the original author(s) or licensor are credited and that the original publication in this journal is cited, in accordance with accepted academic practice. No use, distribution or reproduction is permitted which does not comply with these terms. 